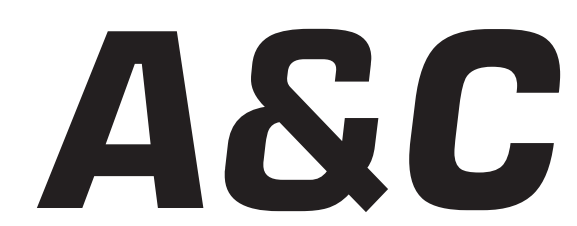

Revista de Direito Administrativo \& Constitucional

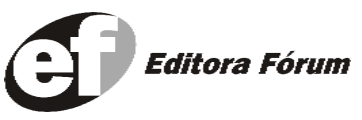

A\&C R. de Dir. Administrativo e Constitucional, Belo Horizonte, ano 6, n. 23, p. 1-253, jan./mar. 2006 


\section{A\&C REVISTA DE DIREITO ADMINISTRATIVO E CONSTITUCIONAL}

\section{IPDA}

Instituto Paranaense

de Direito Administrativo

Direção Geral

Romeu Felipe Bacellar Filho

Direção Editorial

Paulo Roberto Ferreira Motta

Direção Executiva

Emerson Gabardo

Conselho de Redação

Edgar Chiuratto Guimarães

Adriana da Costa Ricardo Schier

Célio Heitor Guimarães

Conselho Editorial

Adilson Abreu Dallari

Alice Gonzáles Borges

Carlos Ari Sundfeld

Carlos Ayres Britto

Carlos Delpiazzo

Cármen Lúcia Antunes Rocha

Celso Antônio Bandeira de Mello

Clèmerson Merlin Clève

Clóvis Beznos

Enrique Silva Cimma

Eros Roberto Grau

Fabrício Motta

Guilhermo Andrés Muñoz (in memoriam)

Jaime Rodríguez-Arana Muñoz

Jorge Luís Salomoni
José Carlos Abraão
José Eduardo Martins Cardoso

José Luís Said

José Mario Serrate Paz

Juan Pablo Cajarville Peruffo

Juarez Freitas

Julio Rodolfo Comadira

Luís Enrique Chase Plate

Lúcia Valle Figueiredo

Manoel de Oliveira Franco Sobrinho

(in memoriam)

Marçal Justen Filho

Marcelo Figueiredo

Márcio Cammarosano

Maria Cristina Cesar de Oliveira
Nelson Figueiredo

Odilon Borges Junior

Pascual Caiella

Paulo Eduardo Garrido Modesto

Paulo Henrique Blasi

Paulo Neves de Carvalho (in memoriam)

Paulo Ricardo Schier

Pedro Paulo de Almeida Dutra

Regina Maria Macedo Nery Ferrari

Rogério Gesta Leal

Rolando Pantoja Bauzá

Sérgio Ferraz

Valmir Pontes Filho

Yara Stropa

Weida Zancaner

\footnotetext{
A246 A\&C Revista de Direito Administrativo e Constitucional. ano 3, n. 11, jan./mar. 2003. Belo Horizonte: Fórum, 2003.

Trimestral

ano 1, n.1, 1999 até ano 2, n.10, 2002 publicada pela Editora Juruá em Curitiba

ISSN: 1516-3210

1. Direito Administrativo. 2. Direito Constitucional. I. Fórum.
}

CDD: 342 CDU: 33.342

(c) Editora Fórum Ltda. 2006

Todos os direitos reservados. É proibida a reprodução total ou parcial, de qualquer forma ou por qualquer meio eletrônico ou mecânico, inclusive através de processos xerográficos, de fotocópias ou de gravação, sem permissão por escrito do possuidor dos direitos de cópias (Lei $n^{\circ}$ 9.610, de 19.02.1998).

Editora Fórum Ltda

Av. Afonso Pena, 2770 - 15\%16ªndar - Funcionários

CEP 30130-007 - Belo Horizonte/MG - Brasil

Tel.: 08007043737

Internet: www.editoraforum.com.br

e-mail: editoraforum@editoraforum.com.br
Editor responsável: Luís Cláudio Rodrigues Ferreira Projeto gráfico e diagramação: Luis Alberto Pimenta Revisora: Olga M. A. Sousa

Pesquisa jurídica: Fátima Ribeiro - OAB/MG 74868

Bibliotecária: Nilcéia Lage de Medeiros

CRB 1545/MG 6a região

Os conceitos e opiniões expressas nos trabalhos assinados são de responsabilidade exclusiva de seus autores.

Impressa no Brasil / Printed in Brazil

Distribuída em todo Território Nacional 


\title{
Parcerias Público-Privadas (PPPs) e desafios regulatórios
}

\author{
Juarez Freitas \\ Professor Titular e Coordenador do Mestrado e do Doutorado em Direito da Pontifícia Universidade \\ Católica do RS, da UFRGS, da Escola Superior da Magistratura (AJURIS). Presidente do Instituto \\ Brasileiro de Direito Administrativo e do IDARGS
}

Sumário: 1 Introdução - 2 PPPs: o modelo brasileiro - 2.1 Da natureza contratual - 2.2 Dos riscos partilháveis - 2.3 Da austeridade fiscal - 2.4 Das garantias especiais ou da "blindagem" - 2.5 Da contraprestação adicional à tarifa - 2.6 Da indelegabilidade - 2.7 Do longo prazo - 2.8 Da vinculação a valor - 2.9 Da avaliação de performance e da remuneração variável - 2.10 Da administração pública como usuária - 2.11 Da concorrência e da figura híbrida - 2.12 Do órgão gestor - 2.13 Da sociedade de propósito específico - 2.14 Da pretensa atualização automática - 2.15 Das competências - 2.16 Da consulta pública ou da preferível audiência pública - 2.17 Do projeto básico - 2.18 Do dever de motivação clara e congruente - 2.19 Da segurança para os financiadores - 2.20 Da resolução de conflitos - 2.21 Do objeto - 2.22 Das normas gerais - 2.23 Dos critérios de julgamento - 2.24 Do índice de desenvolvimento humano - 3 PPP e regulação: mudanças necessárias no ambiente dos negócios públicos - 4 Conclusões

Palavras-chave: Parceria público-privada, Brasil ; Parceria público-privada, legislação, Brasil ; Parceria público-privada, regulação ; Parceria públicoprivada, órgão gestor ; Parceria público-privada, Indice de Desenvolvimento Humano

\section{Introdução}

As parcerias público-privadas (PPPs), embora imprescindíveis ajustes normativos, e a promoção crítica da redefinição regulatória surgem como instrumentos para, sem recorrer à privatização pura e simples, enfrentar os sérios "gargalos" da congestionada infra-estrutura e as graves deficiências na prestação dos serviços universais delegáveis. De forma mais restrita do que no Direito Comparado, as PPPs, no contexto brasileiro, são espécies de "concessões" e, nessa medida, não passam de versões "blindadas" de contratos administrativos bem conhecidos. Teria sido, aliás, juridicamente mais apropriado e técnico, ainda que menos impactante na esfera política, inserir simples retoques às Leis de Concessões e de Licitações. ${ }^{1}$ Soa, de fato, incongruente não reconhecer que a

O exame cuidadoso dos conceitos da Lei n 11.079 mostra que há evidente similitude, no caso da subespécie de "concessão administrativa" (aquela que tem a Administração Pública como usuária direta) com o contrato de prestação de serviços, constante na Lei de Licitações. Já a outra subespécie de "concessão administrativa" (sem cobrança de tarifa e com remuneração incumbindo exclusivamente ao Poder Público, tendo a Administração como usuária indireta), nada mais é do que contrato de concessão de serviços 
contra-prestação adicional ao valor da tarifa pelo Poder Público não desnatura, em nada, o tradicional conceito de concessão: somente o matiza.

Em outras palavras, a seqüência da peculiarização parcial do regime de PPPs exige um plexo pacificador de alterações normativas supervenientes. ${ }^{2}$ Por ora, contudo, a disciplina conceitual das PPPs almeja introduzir garantias adicionais (a chamada "blindagem"), com o fito de atrair investidores para empreendimentos de longo prazo de amortização e de monta (no mínimo, vinte milhões de reais). Tais garantias são coadjuvantes em termos conceituais e só funcionarão se respaldadas por tempestiva declaração de constitucionalidade. Entretanto, há outras garantias, certamente mais importantes e que não constam do atual modelo. São aquelas oriundas do caráter previsível e sensato de um arcabouço regulatório bem pensado. Com efeito, os investidores têm o direito à ciência límpida acerca das titularidades dos serviços delegados (vide o caso emblemático do saneamento) e das respectivas competências fiscalizatórias, evitandose o erro maiúsculo, para ilustrar, de uma Agência Reguladora que faz as vezes de Poder Concedente setorial.

Logo, sem negar o impacto simbólico da Lei $\mathrm{n}^{\circ} 11.079 / 2004$, tal diploma constitui um chamamento adicional a mudanças profundas em nosso Direito Administrativo Regulador. Deveras, a mais expressiva garantia a ser ofertada aos parceiros privados (inclusive nas parcerias em sentido amplo, que não abarcam apenas os contratados nas duas espécies de PPPs) reside no incremento sensível da credibilidade e da confiabilidade institucional do parceiro público. Tudo de molde a fazê-lo eficiente, eficaz e dialógico, além de moderadamente independente das políticas governativas, isto é, situado à parte das variações do humor político transitório e dos contingenciamentos orçamentários indevidos. ${ }^{3}$

públicos, com características peculiares, mas não substancialmente distinto da "concessão comum". Por sua vez, a "concessão patrocinada", aquela em que há contraprestação adicional ao valor da tarifa, só difere da "concessão comum" por aspectos identicamente secundários, entre os quais se destacam a contraprestação pecuniária (vedada na "comum") e a obrigatoriedade de o parceiro privado ser sociedade de propósito específico (ao passo que se admite o contrato associativo de consórcio, no caso da "concessão comum").

2 Entre tais mudanças, há necessidade urgente de bem pensada Lei do Ambiente Regulatório, bem como de Lei Complementar disciplinando o licenciamento ambiental descentralizado e cooperativo. No caso da Lei do Ambiente Regulatório, não se trata de espartilhar as Agências Reguladoras, numa lei homogeneizadora que desconsidere as especificidades, mas de promover a indispensável e criteriosa redefinição do sistema regulatório brasileiro e de seus processos, realizando opções cruciais, no concernente às competências, para a estabilidade regulatória propícia e favorável a ciclos longos de investimentos.

3 Cuidando-se de evitar o excesso de independência das Agências e estruturando o sistema de modo a posicionar o usuário no mesmo plano das entidades reguladas, como sugere, com acerto, no ponto, SUNSTEIN, Cass. O Constitucionalismo Após o The New Deal. In: MATTOS, Paulo (Coord). Regulação Econômica e Democracia. Ed. 34, 2004. p. 137, proposta 8. 
Requer-se clareza solar a respeito de quem fiscaliza, quem decreta a caducidade, quem arbitra (por certo, a arbitragem pública será preferível à privada), quem atualiza (sem a crença ingênua em "atualização automática") e, em suma, quem viabiliza, de modo duradouro, a consistência das relações plurilaterais de parceria. Eis as questões nevrálgicas, pendentes de adequado e firme esclarecimento, indispensável para viabilizar as parcerias em sentido amplo e, notadamente, as PPPs.

A intangibilidade do equilíbrio econômico-financeiro e a regulação adequada são direitos fundamentais dos usuários e de todos os contratados, novos ou antigos, inclusive os impropriamente denominados "concessionários comuns”. Para todos, importa reduzir o risco da indefinição regulatória, o grande inimigo a ser sobrepujado, pois quanto menores as chances de quebra da confiança mútua, menor a demanda de garantias ou "blindagens" especiais. Urge, por isso, frisar que as PPPs não devem ser interpretadas em detrimento dos demais credores públicos (os “comuns”), sob pena de conflitos nefastos e juridicamente injustos.

Tais e outros temas serão versados no presente estudo, que objetiva fixar criticamente as características dos contratos de PPPs e apontar os mais significativos desafios regulatórios.

\section{PPPs: o modelo brasileiro}

Como se trata, ao mesmo tempo, de estudo descritivo e prescritivo, nada mais pertinente do que a fixação inicial das características das PPPs brasileiras. Antes de fazê-lo, útil lançar breves considerações sobre a visão conceitual das PPPs, que prepondera no exterior. Tome-se o exemplo matricial do Reino Unido, cujo entendimento sobre PPPs é assaz pragmático, adaptando conceito que vem do Direito Privado dos fins do século XIX: as PPPs unem, a longo termo, os setores público e privado para mútuos benefícios, ${ }^{4}$ abarcando concessões, ao lado de várias figuras. Portanto, no sistema britânico, as concessões são apenas espécies de PPPs. Ali, são admitidas as PPPs para investimentos os mais variados, seja em instalações hospitalares, passando por escolas, prisões e até contratos de defesa, na maior parte das vezes com economia considerável, todavia sem modelo rígido. Constata-se, de uns tempos para cá, a preocupação crescente de exigir que as várias espécies de PPPs gerem benefícios sociais e econômicos mais efetivos do que os trazidos pelo investimento estatal direto. 4 Vide, por exemplo, Documento HM Treasury (2000) "Public Private Partnerships", que faz balanço elucidativo sobre PPPs no Reino Unido.

A \& C R. de Dir. Administrativo e Constitucional, Belo Horizonte, ano 6, n. 23, p. 145-177, jan./mar. 2006 
Útil perceber, ainda, que as PPPs, no Reino Unido, traduzem notória recusa à privatização pura, não descurando a regência dos serviços universais pelo Direito Administrativo, seja no desenho institucional das contratações, seja na tentativa de regulação compatível e contínua.

O exemplo é mais do que suficiente para os objetivos do presente estudo. ${ }^{5}$ Serve para evidenciar o equívoco dos que supõem que as PPP possam admitir conceito unívoco. À diferença da opção legislativa brasileira, observa-se, na maior parte dos países, a voluntária elasticidade conceitual. ${ }^{6} \mathrm{O}$ exemplo é prestimoso, igualmente, para realçar que o nosso modelo normativo assume características extremadamente restritivas para as PPPs, ao pretender viabilizar as aludidas "blindagens", em face da desconfiança aguda quanto ao adimplemento tempestivo das obrigações pelo Poder Público, mormente em avenças de longo prazo.

Assim, embora doutrinariamente devam ser acolhidas as parcerias em sentido amplo, englobando toda e qualquer vinculação duradoura e continuada do Poder Público com particulares, colimando benefícios mútuos, ${ }^{7}$ as PPPs, em sentido legal, são apenas as "concessões" assim denominadas por opção política do legislador. Nesse enfoque normativo, a parceria público-privada (PPP), em nosso ordenamento, reúne características peculiares e restritivas. Ei-las:

(a) a PPP é um contrato entre parceiros público e privado (numa

\footnotetext{
5 Para uma visão comparada, vide, entre outros, Akintoye, Akintola; BECK, Mathias; HARDCASTLE, Cliff. Public-Private Partnerschips. London: Blackwell Science, 2003. Sobre o imperativo de regular os reguladores, além de temas de extrema importância, vide MCCRUDDEN, Christopher. Regulation and Deregulation. Oxford: Oxford University Press, 1999, p. 3-14. Vide, ainda, Diretrizes sobre as melhores práticas para a a u d t oria de risco n a s P P P , do Grupo de Trabalho de INTOSAI. Nesse documento, opera-se com noção mais

ampla de parcerias (em sentido diverso do art. $2^{\circ}$ da Lei $n^{\circ} 11.079 / 2004$ ), arrolando empresas conjuntas, franquias, $\mathrm{PFI}$, concessões e até participações minoritárias em empresas privatizadas. O fator comum é que o Estado delega elemento do controle do serviço a uma entidade do setor privado. Ainda: a título de cotejo, vide o conceito de PPP em Portugal, mais precisamente o que consta no Decreto-Lei n 86/2003: "entendese por parceria público-privada o contrato ou a união de contratos, por via dos quais entidades privadas, designadas por parceiros privados, se obrigam, de forma duradoura, perante um parceiro público, a assegurar o desenvolvimento de uma atividade tendente à satisfação de uma necessidade coletiva, e em que o financiamento e a responsabilidade pelo investimento e pela exploração incumbem, no todo ou em parte, ao parceiro privado". Verdade que a experiência portuguesa tem sido objeto de duras críticas, que não podem ser abordadas no presente artigo.

6 Bing Li e Akintola Akintoye in ob. cit. apresentam características genéricas das PPPs, quais sejam: a) a partnership involves two or more actors, at least one of which is public; b) each participant is a principal; c) stable relationschip among actors; d) each of the participants brings something to the partnership; e) there is some shared responsibility for outcomes or activities (p. 6). Já os benefícios apontados são: a) enhance government's capacity to develop integrated solutions (ex. Channel Tunnel); b) facilitate creative and innovative approaches; c) reduce the cost to implement the project; d) reduce the time to implement the project; e) transfer certain risks to the private project partner; e) attract larger, potentially more sophisticated, bidders to the project; f) acess skills, experience and technology (p. 7-9).

7 Entre nós, fazendo a distinção entre parcerias em sentido amplo e as PPPs da Lei no 11.079/2004, vide SUNDFELD, Carlos Ari. Guia Jurídico das Parcerias Público-Privadas", Parcerias Público-Privadas. Obra coletiva.
}

A \& C R. de Dir. Administrativo e Constitucional, Belo Horizonte, ano 6, n. 23, p. 145-177, jan./mar. 2006 
relação jurídica plurilateral: poder concedente, concessionário, usuário e regulador), no qual, por definição, o parceiro privado pretende obter lucro, de modo que resultam afastadas desse regime aquelas parcerias (em sentido lato) estabelecidas, por exemplo, com o denominado terceiro setor, tais como as celebradas com as organizações da sociedade civil de interesse público;

(b) a PPP supõe riscos compartilháveis, distribuídos contratualmente de modo a respeitar a eqüidade;

(c) a PPP deve resguardar, com rigor, a Lei de Responsabilidade Fiscal, estabelecidos limites adicionais em relação à receita corrente líquida, que melhor estariam no corpo da Lei Complementar;

(d) a PPP almeja oferecer garantias especiais para o parceiro privado, com a criação discutível, por via ordinária, da vinculação de receitas e do Fundo Garantidor (FGP), supostamente de natureza privada, que, na esfera federal, ${ }^{8}$ apresenta traços curiosos, tais como o da afetação de patrimônio (matéria que reclama respaldo constitucional, seja pela pacificação por via de Emenda, seja por declaração de constitucionalidade);

(e) a PPP, mais precisamente na modalidade "patrocinada", admite, devidamente justificada, a contraprestação adicional ao valor da tarifa, até como estratégia de assegurar a modicidade, vedada a prática de subsídios demagógicos ou contrários à austeridade;

(f) a PPP deve respeitar a indelegabilidade das funções exclusivas do Estado, notadamente as regulatórias ou de "polícia administrativa", relacionadas ao exercício essencial de autoridade instranferível;

(g) a PPP acarreta liame de prazo longo, cuja duração não pode ser menor do que cinco anos (para evitar o enquadramento no prazo máximo constante na Lei de Licitações, art. 57), nem exceder a trinta e cinco anos;

(h) a PPP guarda vinculação a determinado valor (no mínimo, de

\footnotetext{
8 Nos termos do Decreto $n^{\circ}$ 5.411/2005, tendo em vista o disposto no art. 16 da Lei n 11.079/2004, restou autorizada a integralização de cotas em Fundo Garantidor de Parcerias Público-Privadas - FGP, mediante a transferência de ações da União constantes dos Anexos I e II desse Decreto, referentes às suas participações minoritárias e excesso à manutenção do seu controle em sociedades de economia mista. Ficou, ainda, autorizada a integralização com outras ações da União, além das constantes do anexo II do Decreto, não depositadas no FND e no FAD, representativas de suas participações minoritárias em percentual inferior a cinco por cento do capital total da respectiva empresa e do excesso à manutenção do seu controle em sociedades de economia mista.
} 
vinte milhões), inclusive para Estados e Municípios, o que restringe o universo de parceiros públicos, dificuldade mitigada pelo advento da Lei de Consórcios Públicos;

(i) a PPP supõe avaliação constante de performance, admitida a remuneração variável;

(j) a PPP pode ter a Administração Pública como usuária "direta ou indireta", na impropriamente denominada "concessão administrativa";

(k) a PPP deve ser precedida de certame licitatório na modalidade concorrência, ainda que viável a incorporação de aspectos procedimentais do pregão, de modo a termos um híbrido de concorrência e pregão, ou seja, uma combinação problemática sem a devida mudança conceitual no campo das modalidades licitatórias (na Lei de Licitações);

(l) a PPP tem órgão gestor, na esfera federal e no âmbito das Leis estaduais, fortemente vinculado à Administração Direta, num "executivismo" exacerbado, que deveria ser temperado pelo controle social;

(m)a PPP requer sociedade de propósito específico, que terá, observados os padrões de governança corporativa, a incumbência de implantá-la e de geri-la, não se aceitando o consórcio, como no caso da "concessão comum", nem a contratação, em regra, de entidade integrante da própria Administração Pública;

(n) a PPP apresenta duvidoso mecanismo de "atualização automática" ou por decurso do prazo, que supõe extrema eficiência regulatória e, na vida real, pode suscitar conflitos à guisa de evitá-los;

(o) a PPP é fiscalizada pela Administração Direta, pelas Autarquias Reguladoras de regime especial e pelos Tribunais de Contas, nas respectivas competências, não claramente delimitadas;

(p) a PPP deve ser precedida de Consulta Pública quanto à minuta do edital, mas melhor seria cobrar a Audiência Pública, à luz da Constituição;

(q) a PPP admite, não sem alta dose de ousadia, que o particular elabore o projeto básico, não apenas o projeto executivo, em função de veto presidencial;

(r) a PPP deve ser motivada, quanto às "vantagens socioeconômicas" e "sustentabilidade", convindo perceber que, como na "concessão comum” o Poder Concedente não remunera pecuniariamente,

A \& C R. de Dir. Administrativo e Constitucional, Belo Horizonte, ano 6, n. 23, p. 145-177, jan./mar. 2006 
deve-se sempre preferi-la, quando possível, em vez da "concessão patrocinada" ou da "concessão administrativa";

(s) a PPP quer propiciar maior segurança para os financiadores, por meio de mecanismos peculiares, tais como o empenho em nome deles;

(t) a PPP, almejando promover a solução mais rápida para conflitos, apela à arbitragem privada, ainda que esta não possa substituir a função regulatória estatal, nem versar sobre direitos indisponíveis, motivo pelo qual o melhor seria - e é - incentivar mecanismos públicos de resolução célere dos conflitos;

(u) a PPP não se confunde com terceirização, vedado tal ajuste quando o único objeto for o fornecimento de mão-de obra;

(v) a PPP é introduzida por "normas gerais", que não podem ostentar a nota de subsidiariedade em relação a outras "normas gerais", a despeito da letra equivocada da lei;

(x) a PPP pode ter licitação que agasalhe critérios que incluam o exame de menor valor da contraprestação e a inversão da ordem das fases de habilitação e julgamento, providência esta última que deve ser ampliada para as "concessões comuns";

(z) a PPP apresenta limites que oscilam, ao menos em alguns casos, conforme o Índice de Desenvolvimento Humano e indevidamente segundo regiões.

\subsection{Da natureza contratual}

Quanto à natureza contratual da PPP, frise-se que, apesar das aparências, não se trata de contrato genuinamente novo. A par disso, foi equívoco cogitar apenas de concessão como PPP, excluindo, por exemplo, as permissões (em contraste até com leis estaduais). ${ }^{9} \mathrm{~A}$ explicação (não justificativa) está na pretensão de compor a "blindagem" das PPPs, inexistindo recursos para expandir e universalizar tais garantias mais robustas. Melhor seria, contudo, que o legislador não houvesse realizado a opção restritiva. A despeito dessa crítica, o certo é que a Lei ${ }^{\circ} 11.079$ apresenta a parceria público-privada como uma concessão, nas moda-

\footnotetext{
${ }^{9}$ Mesmo legislação estadual mais abrangente - como é o caso da Lei n $12.234 / 2005$, art. 20 ${ }^{\circ}$ ao conceituar as parcerias no Rio Grande do Sul (em linhas gerais, ajuste entre a Administração Pública em que haja investimento privado) — terá de ser lida em sintonia com a Lei $n^{\circ} 11.079 / 2004$, que fixa normas gerais sobre a matéria, não se admitindo, infelizmente, a permissão, prevista no art. 11 como PPP no RS.
} 
lidades "patrocinada" e "administrativa."10

A “concessão patrocinada” é entendida como espécie de delegação da execução de serviços públicos ou de obras públicas que envolve, adicionalmente à tarifa cobrada dos usuários, a contraprestação pecuniária pelo parceiro público. ${ }^{11}$ Bem entendida, nada mais é do que uma concessão que não destoa, no âmago, do conceito previsto no art. $2^{\circ}$ da Lei de Concessões, com o acréscimo secundário da admissibilidade de contraprestação adicional (não exclusiva) do Poder Público. Mais técnico seria, em vez de "patrocinada", denominá-la "concessão subvencionada", ${ }^{12}$ porque supõe uma subvenção, vale dizer, a remuneração parcial à conta do parceiro público, destinada a assegurar a modicidade das tarifas e sem afastar receitas alternativas (ponto que merece ser sublinhado). ${ }^{13}$ Observada com cuidado, nada mais se vê do que uma concessão, vale dizer, uma delegação, por "conta e risco", com a peculiaridade apenas da contraprestação adicional que a viabiliza e a faz sustentável. Com efeito, a concessão de serviços públicos, em sentido lato, pode ser definida como a delegação da prestação de serviço público — efetuada pela entidade estatal em cuja competência se encontra tal serviço - , por meio de contrato administrativo, precedido de licitação, por prazo determinado e por risco próprio, com ou sem a subvenção remuneratória pelo Poder Público (como no caso das PPPs), ${ }^{14}$ em harmonia com os princípios regentes da Administração Pública, inclusive o da economicidade e o da imparcialidade. Como se nota, de modo insofismável, o conceito de "parceria subvencionada" não colide, no cerne, com o da "concessão comum", nada obstante a presença das notas acidentais, introduzidas para alcançar a referida "blindagem".

Portanto, no Brasil, seguem duas grandes modalidades de contratos

\footnotetext{
${ }^{10}$ A teor do art. $2^{\circ}$ da Lei no 11.079/2004: "Parceria público-privada é o contrato administrativo de concessão, na modalidade patrocinada ou administrativa"

11 Traduzível em pecúnia, para ser mais exato.

12 Preferível, ainda que com possíveis ressalvas em face da polissemia em nosso sistema, tal expressão àquela contida no texto normativo ("concessão patrocinada"), assim como melhor do que concessão subsidiada, embora esta última não esteja propriamente errada. Importa, de qualquer modo, ter presente, para os efeitos da opção terminológica, por exemplo, a incidência do art. 26 da Lei Complementar no 101/2000 (LRF), ou seja, ali se prescreve que a destinação de recursos públicos deve atender às condições estabelecidas na lei de diretrizes orçamentárias e estar prevista no orçamento ou em seus créditos adicionais, fazendo menção expressa às subvenções. Sobre o termo em sentido diverso parcialmente, vide BORGES, Souto Maior. Subvenção Financeira, Isenção e Deduções Tributárias. Revista de Direito Público, v. 41 e 42, p. 43, distinguindo-a da mera isenção.

${ }^{13}$ Receitas alternativas que derivam da aplicação do art. 18 da Lei n 8.987/95, VI, com expressa remissão no art. $5^{\circ}$, VIII da Lei de PPPs.

${ }^{14}$ Desaconselhável, cientificamente, enquadrar o ajuste com remuneração integral pelo Poder Público como concessão em sentido próprio, apesar da dicção do art. $2^{\circ}$ da Lei $n^{\circ}$ 11.079: semelhante visão literal infirma, sem vantagens, a acepção generalizada do instituto.
} 
administrativos: (I) os que implicam delegação da execução indireta de serviços públicos e (II) os que acarretam prestações à própria Administração Pública (sem delegação). O regime de PPPs veio produzir alterações pontuais no regime de ambos, não a ponto de fazer genuína essa modalidade de contratação. Elucide-se, a propósito, que, quanto ao modo de remuneração, há lugar para três espécies de contratos administrativos: (i) ajustes com remuneração a cargo do usuário final ("concessão tradicional" ou "comum”) e, residualmente, receitas alternativas (não públicas), nos termos do art. 18, VI da Lei $n^{\circ} 8.987 / 95$; (ii) ajustes com remuneração parcial por meio de recursos públicos "lato sensu" ("concessão patrocinada" ou "subvencionada", como parece preferível nominar), além de tarifa e das aludidas receitas alternativas e (iii) ajustes com remuneração à conta exclusiva do Poder Público (aqui enquadrada a "concessão administrativa”, mas não só).

Nesse cenário, resulta que apenas pode haver PPPs, no sistema normativo vigente, nas hipóteses (ii) e (iii), não na hipótese (i). Mais: será sempre preferível, por economicidade, a primeira hipótese (i) na comparação com as duas outras. Por idêntico raciocínio, deve ser preferida a hipótese (ii) em relação à hipótese (iii). Assim, sempre que viável, o Poder Concedente deve optar pela "concessão comum", em lugar da "concessão patrocinada" ou da "concessão administrativa”. Sem prejuízo disso, com a devida motivação, nada impede, observadas as exigências legais, transformar a "concessão comum" em "patrocinada" ou "administrativa." ${ }^{5}$

Nominalismos à parte, a "concessão administrativa" surge como

\footnotetext{
${ }^{15}$ Registre-se que, no caso da pioneira Lei Estadual no 14.868/2003, de Minas Gerais, no art. 10, as parcerias público-privadas são apresentadas como contratos de colaboração entre o Estado e o particular, por meio dos quais o ente privado participa da implantação e do desenvolvimento de obra, serviço ou empreendimento público, bem como da exploração e da gestão das atividades deles decorrentes, cabendo-lhes contribuir com recursos e sendo remunerado segundo o seu desempenho. Apesar de imperfeições, verifica-se que, a rigor, nesse diploma estadual, não se vislumbra contrato genuíno, mas modo peculiar de apresentação dos contratos administrativos citados. Observe-se a preocupação de não considerar PPP, a teor do art. $5^{\circ}, \S 2^{\circ}$, entre outras hipóteses, a realização de obra sem o encargo de mantê-la por certo período, nem a terceirização, tampouco a prestação isolada. Por igual, já negava a PPP em função do prazo ou do valor (inc. IV). No caso $\quad$ d $\quad$ a $\quad L \quad$ e i Estadual no 11.688/2004, que introduziu PPPs em São Paulo, as parcerias são entendidas como mecanismos de colaboração entre o Estado e agentes do setor privado, remunerados segundo critérios de desempenho, em prazo compatível com a amortização dos investimentos realizados, podendo ter por objeto a implantação, ampliação, melhoramento, reforma, manutenção ou gestão de infra-estrutura pública, a prestação de serviço público, a exploração de bem público; a exploração de direitos de natureza imaterial de titularidade do Estado. Cuida, também, de excluir a mera terceirização de mão-de-obra e as prestações singelas ou isoladas. Reconhece, em sintonia parcial com a Lei Federal, que os contratos reger-se-ão pelas normas gerais sobre licitações e contratos administrativos, devendo estabelecer metas, os resultados a serem atingidos e os respectivos prazos de execução ou cronograma, bem como critérios objetivos de avaliação de desempenho e a possibilidade de compartilhamento dos ganhos decorrentes da modernização, expansão ou racionalização das atividades desenvolvidas pelo contratado. Não destoam, nas grandes linhas, as Leis
} 
outra modalidade contratual de PPP, na qual a Administração Pública figura como usuária "direta ou indireta", ainda que envolva a execução de obra ou fornecimento e instalação de bens $\left(\operatorname{art} .2^{\circ}\right),{ }^{16}$ desde que com riscos partilhados. Ora bem, insofismável que o legislador equivocou-se ao cogitar da "concessão administrativa". Primeiro, porque todo contrato de concessão é "administrativo". Segundo, porque não se trata, a rigor, de concessão, mas pode ser, ao menos numa de suas variantes, um contrato de prestação de serviço à Administração Pública, na hipótese em que a Administração Pública é "usuária direta", com o grande traço peculiarizador ${ }^{17}$ de exigir investimento privado de, no mínimo, vinte milhões. Aqui, não acontece, em sentido próprio, delegação, por "conta e risco", salvo no caso da concessão de serviços públicos em que a remuneração incumbe exclusivamente à Administração Pública ("usuária indireta"). Logo, não se está necessariamente perante concessão na linha conceitual proposta (que implica delegação), uma vez que pode ocorrer mera contratação administrativa peculiar (com prazo mais longo, entre outras distinções), que se deve encapsular no conceito elástico e abrangente do art. $2^{\circ}$ da Lei de Licitações, com o leque de consectários em matéria de regime aplicável. Sim, a definição legal de contrato, prevista no parágrafo único do art. $2^{\circ}$ da Lei $n^{\circ}$ 8.666/93 ("todo e qualquer ajuste entre órgãos ou entidades da Administração Pública e particulares, em que haja um acordo de vontade para a formação de vínculo e a estipulação de obrigações recíprocas, seja qual for a denominação utilizada”), a despeito de falhas técnicas (por exemplo, não somente particulares podem figurar como contratados, tampouco existe necessariamente estipulação de obrigações recíprocas, assim como se mostra indevida a alusão a órgãos), atina, a seu modo, para o devido elastério do objeto, na perspectiva de não subtrair o Poder Público dos deveres ali constantes, além de provocar idêntico efeito em relação a pactos historicamente tidos como de Direito Privado, os quais devem resguardar isonomia e moralidade administrativa. ${ }^{18}$

Mais cientificamente acertado seria reconhecer que somente

\footnotetext{
${ }^{16}$ Art. $3^{\circ}$ As concessões administrativas regem-se por esta Lei, aplicando-se-lhes adicionalmente o disposto nos arts. 21, 23, 25 e 27 a 39 da Lei n 8.987, de 13 de fevereiro de 1995, e no art. 31 da Lei n 9.074, de 7 de julho de 1995.

${ }^{17}$ Carlo Ari Sundfeld in ob. cit., p. 30-31, embora, com acerto, diga que não se trata de simples contrato de prestação de serviços, dado seu objeto mais complexo, não deixa de notar que tem, a rigor, por objeto os mesmos serviços referidos no art. $6^{\circ}$ da Lei $n^{\circ} 8.666 / 93$.

18 Para aprofundar, vide FREITAS, Juarez. O Controle dos Atos Administrativos e os Princípios Fundamentais. 3. ed. São Paulo: Malheiros, 2004. Cap. 11.
} 
existem, a rigor, dois grandes tipos de contratos administrativos: os definidos no art. $2^{\circ}$ da Lei de Concessões e os abrangidos no art. $2^{\circ}$ da Lei de Licitações. "Tertium non datur". Nessa senda, não se afigura da melhor técnica a assertiva de que continuam regidos exclusivamente pela Lei $\mathrm{n}^{\circ}$ 8.666/93 os contratos que não caracterizem concessão comum, patrocinada ou administrativa (art. $3^{\circ}$, parágrafo $3^{\circ}$ da Lei $n^{\circ} 11.079 / 2004$ ), pois dá a impressão de que a "concessão administrativa" pode não observar boa parte das normas gerais da Lei de Licitações. Também cai numa tentação arbitrária a opção normativa de que não constituiria parceria públicoprivada a "concessão comum", assim entendida a concessão de que trata a Lei no $8.987 / 95$, simplesmente por não envolver contraprestação pecuniária do parceiro público. Melhor doutrinariamente é considerar a parceria público-privada de maneira a englobar contratos peculiares de concessão e os não menos peculiares contratos de prestação direta à Administração Pública, acolhendo os inegáveis pontos de convergência.

De mais a mais, importa salientar que as PPPs, previstas na Lei $\mathrm{n}^{\mathrm{o}} 11.079 / 2004$, são, como todos os contratos que se aperfeiçoam pela presença da Administração Pública num dos pólos da avença formal, regidos por princípios publicistas (nesse aspecto, transcendendo o chamado, com alguma imprecisão, Direito Comum). Com objeto público e sob o controle alargado no tocante à licitude, devem observar quando houver dispêndio - a previsão orçamentária e a responsabilidade fiscal ${ }^{19} \mathrm{e}$, salvo nas hipóteses de dispensa ou inexigibilidade (devidamente motivadas), precisam ser precedidos do procedimento administrativo endereçado à escolha, com impessoalidade e economicidade, da proposta mais vantajosa para o interesse público. Reitera-se: conquanto viável a conversão, preenchidos os requisitos, de "concessão comum" em "patrocinada” ou "administrativa”, mostra-se sempre preferível realizar a contratação de "concessão comum”, dado que se revela a mais

\footnotetext{
${ }^{19}$ Vide $\mathrm{o}$ art. $7^{\circ}$ e 42 da Lei Complementar no 101/2000 (Lei de Responsabilidade Fiscal). A calhar, cite-se o art. $1^{\circ}, \S 1^{\circ}$, ao assinalar que a responsabilidade fiscal pressupõe a ação planejada e transparente, por meio da qual se previnem riscos e corrigem desvios capazes de afetar o equilíbrio das contas públicas. Vide $o$ art. $9^{\circ}$, consoante o qual os recursos vinculados à finalidade específica serão utilizados exclusivamente para atender ao objeto da vinculação, ainda que em exercício diverso daquele em que ocorrer o ingresso. Vide, com atenção especial, o art. 16 sobre a criação, expansão ou aperfeiçoamento de ação governamental que acarrete aumento da despesa que deve ser acompanhado de estimativa do impacto orçamentáriofinanceiro no exercício em que deva entrar em vigor e nos dois subseqüentes, assim como da declaração do ordenador da despesa de que o aumento tem adequação orçamentária e financeira com a lei orçamentária anual e compatibilidade com o plano plurianual e com a lei de diretrizes orçamentárias. Vide, ainda e especialmente, os arts. 25, 26, 40, 42, 44 e 72 da LRF.
} 
econômica para o erário.

\subsection{Dos riscos partilháveis}

A PPP supõe riscos "objetivamente" compartilháveis. Trata-se de uma das diretrizes superiores ${ }^{20}$ dessa modalidade de contratação (arts. $4^{\mathrm{o}}$, VI e $5^{\mathrm{o}}$, III da Lei $\left.\mathrm{n}^{\mathrm{o}} 11.079 / 2004\right)$, a saber, a repartição de riscos entre as partes, inclusive os referentes a caso fortuito, força maior, fato do príncipe e álea econômica extraordinária. Importa grifar: a "repartição objetiva" de riscos entre as partes não significa inviabilidade de remuneração às custas somente da Administração Pública, na denominada "concessão administrativa". O risco compartilhado, porém, precisa estar presente. À evidência, o risco estará maiormente explícito nas concessões subvencionadas, pois, por definição, requerem a contraprestação adicional pelo parceiro público.

Inadequado asseverar que a repartição de riscos (art. 5 ${ }^{\circ}$, III), implique qualquer alteração no regime de responsabilidade. Mantém-se, intacta, a responsabilidade objetiva do parceiro privado, se prestador de serviços públicos, bem como a responsabilidade subsidiária do parceiro público, não solidária (salvo no caso de danos ambientais), sendo nulo pactuar em contrário. ${ }^{21}$ Tudo leva a crer, portanto, que o reiterado apelo legislativo à objetividade na repartição dos riscos pretende tão-só contribuir à mais célere recomposição do equilíbrio econômico-financeiro. Nessa ótica, a característica apresenta-se intimamente associada àquela da "atualização automática" (art. $5^{\circ}, \S 2^{\circ}, \mathrm{I}$ ), examinada adiante. Ora, se esse é o desiderato, internacionalmente perseguido, a solução tranquilizadora para os parceiros privados, em sede de partilha dos riscos, reside na fixação das regras e dos princípios do processo regulatório (ex.: prazo da promoção de reequilíbrio contratual), na redução real dos riscos regulatórios e na cultura efetiva da proporcionalidade ${ }^{22}$ e de "accountability" na gestão e alocação dos riscos, associados ao incentivo à eficiência ${ }^{23}$ e sem prejuízo do rigoroso controle de acompanhamento no tocante à responsabilidade fiscal. Tudo isso demanda planejamento de longo prazo, bem pouco usual em nosso ambiente. ${ }^{24}$ Derradeiro aspecto merece

20 Sobre as diretrizes, vide Helio Saul Mileski no Especial sobre PPP, na Revista Interesse Público 29.

${ }^{21}$ Sobre tal regime de responsabilidade, vide FREITAS, Juarez. O Controle dos Atos Administrativos e os Princípios Fundamentais, op. cit. Cap. 11.

${ }^{22}$ Por exemplo, na fixação do prazo razoável para a correção de falhas, exigência do art. 38, §3 da Lei $n^{\circ}$ 8.987/95, aplicável na matéria.

${ }^{3}$ Vide GROUT, Paul. Public and Private sector Discount rates in Public-Private Partnerships. The Economic Journal, n. 103, 2003. 
menção: quanto maior o risco, maior o prêmio. Por isso, mostra-se de todo conveniente ao parceiro público empenhar-se para, na fixação da equação econômico-financeira, reduzir, ao máximo, os riscos para os investidores, à diferença do que poderia imaginar o observador menos experiente ou sagaz.

\subsection{Da austeridade fiscal}

A PPP deve resguardar, com ênfase, a Lei de Responsabilidade Fiscal, admissíveis limites adicionais em relação à receita corrente líquida. ${ }^{25} \mathrm{Com}$ efeito, o art. $4^{\mathrm{o}}, \mathrm{IV}$, da Lei $\mathrm{n}^{\mathrm{o}} 1.079$ estabelece a responsabilidade fiscal como diretriz inarredável das contratações de PPPs e o seria, antes disso, por força da Lei Complementar $\mathrm{n}^{\circ} 101$, que, não por acaso, tem vários dos seus dispositivos reproduzidos no corpo da Lei de PPPs. Para ilustrar: nos termos do art. 10, o legislador ordinário condiciona a abertura do processo licitatório à autorização da autoridade competente, fundamentada em estudo técnico que demonstre que as despesas criadas ou aumentadas não afetarão as metas de resultados fiscais previstas no Anexo referido no $\S 1^{\circ}$ do art. $4^{\mathrm{o}}$ da Lei Complementar $\mathrm{n}^{\mathrm{o}} 101,{ }^{26}$ devendo os efeitos financeiros, nos períodos seguintes, ser compensados pelo aumento permanente de receita ou pela redução permanente de despesa. E, "quando for o caso", determina a observância das condições decorrentes da aplicação dos arts. 29, 30 e 32 da Lei Complementar no 101/2000. Reforça, ademais, o que consta na Lei Complementar, ao determinar a elaboração da estimativa do impacto orçamentário-financeiro nos exercícios em que deva vigorar o ajuste e a declaração do ordenador da despesa de que as obrigações contraídas pela Administração Pública no curso do contrato são compatíveis com a lei de diretrizes orçamentárias e se encontram previstas na lei orçamentária anual. Para além disso, foi vetado dispositivo (Lei $\mathrm{n}^{\mathrm{o}}$ 11.079/2004, art. 28, parágrafo $3^{\circ}$ ), justamente para inibir a contratação de PPP apta a comprometer a solvência pública. Nessa trilha

\footnotetext{
${ }^{24}$ Vide VALLE, Vanice Regina Lírio do. Parcerias Público-Privadas e Responsabilidade Fiscal: uma Conciliação Possível. Rio de Janeiro: Lumen Juris, 2005.

${ }^{25}$ Se é certo que ninguém de sã consciência deve debilitar a Lei de Responsabilidade Fiscal, impõe-se corrigir a sua má interpretação. Dessa maneira, sem alteração do texto da Lei de Responsabilidade Fiscal, conveniente reinterpretar, por exemplo, o conceito de receita corrente líquida, tendo em vista as vinculações constitucionais supervenientes à LC no 101/2000, as quais podem, em razão disso, ser criteriosamente excluídas do cômputo.

${ }^{26}$ Vide o art. $4^{\circ}$ da LRF: A lei de diretrizes orçamentárias atenderá o disposto no $\$ 2^{\circ}$ do art. 165 da Constituição e: (...) $\S 1^{\circ}$ Integrará o projeto de lei de diretrizes orçamentárias Anexo de Metas Fiscais, em que serão estabelecidas metas anuais, em valores correntes e constantes, relativas a receitas, despesas, resultados nominal e primário e montante da dívida pública, para o exercício a que se referirem e para os dois seguintes.
} 
salutar de austeridade, o legislador ordinário fez questão de elucidar que serão aplicáveis as penalidades previstas na Lei dos Crimes Fiscais (art. 29 da Lei $\left.n^{\circ} 11.079 / 2004\right)$.

Polêmica mais aguda há quanto aos limites do comprometimento da receita corrente líquida. O nó hermenêutico a ser desatado, nesse passo, consiste em saber se a responsabilidade fiscal justifica a imposição de determinados limites "adicionais" por lei ordinária. Exemplos: o art. 22 da Lei de PPPs veda contratação pela União de PPPs quando a soma das despesas de caráter continuado derivadas do conjunto das parcerias contratadas tiver excedido, no ano anterior, a um por cento da receita corrente líquida e as despesas anuais dos contratos vigentes, nos dez (não nos trinta e cinco) anos subseqüentes, não excedam a um por cento da receita corrente líquida projetada. São, a par disso, estabelecidos limites no art. 28, vedando à União conceder garantia e realizar transferência voluntária aos Estados, Distrito Federal e aos Municípios se a soma das despesas de caráter continuado derivadas do somatório das parcerias contratadas ultrapassar um por cento da receita corrente líquida do exercício ou se as despesas anuais dos contratos vigentes nos dez anos seguintes excederem a um por cento da receita corrente líquida projetada. Indaga-se: lei ordinária pode estabelecer sublimites ou limites "adicionais" àqueles previstos na LRF? Tal questão desborda do presente estudo, porém, de passagem, convém assinalar que se a Lei de PPPs exige aplicação fiscalmente responsável, já por envolver contratações de longo prazo e de grande vulto, já por introduzir garantias especiais, então os limites adicionais não configuram, em princípio, desvio de finalidade normativa ou discrepância com a LRF. Outro aspecto digno de nota é que falta esclarecer, vez por todas, no plano normativo, as hipóteses em que a contraprestação do Poder Público representa endividamento e aquelas outras em que acarreta despesa de caráter continuado. Tal distinção, sim, revela-se chave em termos de conformidade com os limites da Lei de Responsabilidade Fiscal.

\subsection{Das garantias especiais ou da "blindagem"}

Os contratos de PPPs veiculam cláusulas com garantias especiais para o parceiro privado, ${ }^{27}$ inclusive vinculação de receitas (discutível por via legislativa ordinária) e Fundo fiduciário (de natureza "privada", para evitar a burla frontal do art. 100 da CF, não submetido a contingencia-

A \& C R. de Dir. Administrativo e Constitucional, Belo Horizonte, ano 6, n. 23, p. 145-177, jan./mar. 2006 
mento e com eventual afetação de patrimônio). Em realidade, a melhor técnica recomendaria que boa parte desses mecanismos tivesse assento em Emenda Constitucional. Agora, só a declaração de constitucionalidade poderá trazer segurança aos investidores. Desde logo, entretanto, convém assinalar que não se pode prejudicar os credores públicos e os "contratados comuns". Em outras palavras, a "vinculação" não pode redundar em precedência quanto ao custeio (ex: nas áreas de saúde e de educação, que guardam vinculação constitucional). Qualquer primazia, se houver, deve cingir-se ao pagamento, não propriamente à liberação dos recursos. Jamais se deve admitir que os credores do Poder Público sejam divididos entre os de primeira categoria e os integrantes da classe dos virtualmente excluídos. A discriminação negativa mostra-se, por inteiro, inaceitável.

Assim, no rol das garantias que intentam a "blindagem", cumpre destacar que as obrigações pecuniárias contraídas pela Administração Pública em contrato de PPP, consoante dispõe o art. $8^{\circ}$, poderão ser asseguradas mediante vinculação de receitas, (exceto se se tratar de impostos e nas demais hipóteses previstas no art. 167, IV, da CF, com a redação dada pela Emenda Constitucional no 42/2003), bem como pela utilização de fundos especiais, contratação de seguro-garantia junto a seguradoras não-controladas pelo Poder Público, garantia prestada por organismos internacionais ou instituições financeiras não-controladas pelo Poder Público, garantias prestadas por fundo fiduciário e até por empresa estatal criada para essa finalidade. ${ }^{28}$ Reprise-se que mais aconselhável teria sido o advento de Emenda Constitucional a evitar dúvidas quanto à higidez de tais obrigações.

\subsection{Da contraprestação adicional à tarifa}

Na modalidade de "concessão patrocinada", admite-se, no modelo brasileiro, a contraprestação adicional ao valor da tarifa, desde que, convém notar, não se mostre viável a "concessão comum", isto é, a via exclusiva da tarifa ou das receitas alternativas. É imperativo, pois, justificar qualquer contraprestação pecuniária, em homenagem a vários princípios, notadamente o da economicidade (dever de escolher os meios menos onerosos para o erário). A referida contraprestação da Administração Pública, nos

\footnotetext{
${ }^{27}$ Naturalmente, sem prejuízo das garantias que o parceiro privado deve oferecer, compatíveis com os ônus e os riscos envolvidos (art. 50, VIII da Lei $n^{\circ}$ 11.079/2004). Vide, ainda, o art. 56 da Lei n 8.666/93.

${ }^{28}$ Solução adotada, não sem críticas, pela Lei de PPP de São Paulo.
}

A \& C R. de Dir. Administrativo e Constitucional, Belo Horizonte, ano 6, n. 23, p. 145-177, jan./mar. 2006 
termos do art. $6^{\circ}$, ocorre por ordem bancária, cessão de créditos nãotributários, outorga de direitos em face da Administração Pública ou sobre bens públicos dominicais, sem prejuízo de outros meios. Ainda: o contrato poderá prever o pagamento ao parceiro privado de remuneração variável de acordo com o desempenho. ${ }^{29}$

Tal contraprestação da Administração Pública será obrigatoriamente precedida da disponibilização do serviço objeto do contrato de parceria público-privada, evitando-se o absurdo da remuneração sem a devida prestação: só se remunera serviço disponível. Dito de outro modo, para ilustrar, no período de construção de uma rodovia, mediante concessão "patrocinada", não haverá remuneração. Sem embargo, faculta-se à Administração Pública efetuar o pagamento da contraprestação relativa à parcela fruível do objeto do contrato.

\subsection{Da indelegabilidade}

A PPP deve respeitar a indelegabilidade de funções exclusivas do Estado. Convém, nesse passo, enaltecer que, assim como nas Leis Estaduais, a Lei $\mathrm{n}^{\circ}$ 11.079/2004 deixa expresso que, na contratação de PPP, uma das diretrizes a observar é a indelegabilidade de determinados serviços estatais, elencando, de modo não-exaustivo, as funções de regulação e do exercício do "poder de polícia". (art. 4, III). Claro que as atividades reputadas exclusivas do Estado jamais serão delegáveis, por meio de PPPs,${ }^{30}$ tampouco por meio de "concessões comuns". Naturalmente, serão delegáveis as atividades instrumentais ou secundárias. Por exemplo, nos dias atuais, a segurança pública é, fora de dúvida razoável, uma atividade de delegação vedada, mas não o será a atividade relativa à mera hospedaria em presídios. Aqui, um dos desafios para a elaboração científica, no novo Direito Administrativo, que reclama melhor definição das funções exclusivas de Estado, com a conseqüente valorização das carreiras incumbidas de tais tarefas.

\subsection{Do longo prazo}

A PPP é contrato de longa duração, que não pode ser inferior a

\footnotetext{
${ }^{29}$ Vide art. 50, VII da Lei de PPPs.

${ }^{30}$ A Emenda Constitucional $n^{\circ} 42$ definiu expressamente a Administração Tributária como atividade exclusiva de Estado. Falta um mais abrangente mapeamento doutrinário e normativo do conjunto de tais atividades. A Lei $n^{\circ} 12.234 / 2005$ do Rio Grande do Sul, a título de registro, deixa expresso que é indelegável a defesa judicial da Administração Direta e Indireta, assim como as atividades fazendárias (art. 2º, IV).
} 
cinco anos (para não cair no prazo máximo constante na Lei de Licitações), nem exceder a trinta e cinco anos. Relevantíssimo: ao contrário do que faz crer a leitura de superfície ou marcada por impulsividade, essa limitação não prejudica, necessariamente, leis especiais. ${ }^{31} \mathrm{Em}$ outras palavras, não estão excluídas normas setoriais, sobremodo porque, em princípio, quanto maiores os prazos de amortização, maior a modicidade das tarifas e das eventuais contraprestações. Nessa linha, nada impede, por exemplo, na esfera federal, parcerias de prazos mais longos do que os previstos como prazo máximo geral, na Lei de PPPs, desde que com expressa previsão em norma especial. A antinomia, se houver, resolver-se-á de acordo com a velha máxima de que o especial prepondera em relação ao geral, notadamente pela hierarquização superior do interesse público. De qualquer sorte, como norma geral, nos termos do art. $5^{\circ}$ da Lei $n^{\circ} 11.079 / 2004$, cláusula do contrato de PPP deve prever prazo justificadamente compatível com a amortização dos investimentos realizados, não superior a trinta e cinco anos, incluindo eventual prorrogação. Como enfatizado, ao vedar a PPP para contrato cujo período de prestação do serviço for inferior a cinco anos, quis o legislador diferenciá-la em relação ao regime da Lei de Licitações, na hipótese das denominadas "concessões administrativas", mais precisamente no caso em que a Administração Pública figura como "usuária direta", uma vez que, nessa variante, nada mais são do que contratos de prestação de serviços, a teor do mencionado art. $2^{\circ}$ da Lei de Licitações.

\subsection{Da vinculação a valor}

A PPP encontra-se vinculada a determinado valor, numa opção política de duvidosa correção federativa. Compreensível para fazer a seleção dos contratos a serem "blindados" e evitar desvios de toda ordem, mas comporta o risco de inviabilizar as PPPs em vários Municípios (não obstante o advento da Lei de Consórcios Públicos). ${ }^{32}$ Para mais adiante, a confirmar a experiência, recomendável rever o parâmetro em tela. Por ora, trata-se de vedação expressa contida no art. $2^{\circ}, \S 4^{\circ}, \mathrm{I}$, da Lei $\mathrm{n}^{\mathrm{o}}$ 11.079/2004: ali não se permite a PPP em contrato cujo valor seja infe${ }^{31}$ Preservado o prazo da Lei no 8.630/93, sem excluir, por inteiro, PPPs no setor.

32 Com a Lei no 11.107/2005, apesar de dispositivos de redação polêmica, surgiram normas gerais para a União, os Estados, o Distrito Federal e Municípios contratarem consórcio públicos tendo como meta a realização de objetivos de interesse comum, ("associação pública" ou pessoa jurídica de direito privado). Tais consórcios, na dicção legal, poderão outorgar concessão, permissão ou autorização de obras ou serviços públicos. Mais: deverão ser constituídas e reguladas por "contrato de programa" as obrigações que um ente da Federação assumir para com outro no âmbito de gestão associada em que haja prestação de serviços públicos ou a transferência total ou parcial de encargos, serviços, pessoal ou de bens necessários à continuidade dos serviços transferidos. 
rior a vinte milhões de reais. Como asseverado, a intenção foi a de, em relação a contratos de maior vulto e prazo dilatado de amortização, assegurar recursos suficientes para oferecer as garantias do FGP, entre outras igualmente não-universalizáveis.

\subsection{Da avaliação de performance e da remuneração variável}

A PPP supõe avaliação constante de performance. Conveniente grifar que, a rigor, tal característica deve ser reconhecida como inerente às contratações administrativas em geral. No diploma em comento, entretanto, resulta expresso que, entre as cláusulas (art. 5 ${ }^{\circ}$, VII, da Lei $\mathrm{n}^{\mathrm{o}}$ 11.079/2004), devem figurar critérios objetivos de avaliação do desempenho do parceiro privado, inclusive o compartilhamento com a Administração Pública de ganhos econômicos decorrentes da redução do risco de crédito dos financiamentos utilizados pelo parceiro privado. ${ }^{33}$ O contrato de PPP deverá (embora o art. $6^{\circ}$ diga "poderá") prever o pagamento ao parceiro privado de remuneração variável conforme o seu desempenho, atendendo metas e padrões de qualidade bem definidos. Sublinhe-se: essa característica precisa ser universalizada, ou vista como universal, não subsistindo motivo razoável para adiar sua inserção nos demais contratos administrativos.

\subsection{Da administração pública como usuária}

A "concessão administrativa” admite a Administração Pública como usuária "direta ou indireta." Frise-se que as "concessões administrativas" regem-se pela Lei $n^{\circ} 11.079 / 2004$ e, adicionalmente, pelas Leis de Licitações e de Concessões. Se a Administração Pública for usuária direta, trata-se de contratação prestacional de serviço, não propriamente de concessão. A peculiarização decorre, aqui, de não haver como objeto único o fornecimento de mão-de-obra, a instalação de equipamentos ou a execução de obra pública (art. $2^{\circ}$, parágrafo $4^{\circ}$, III da Lei de PPPs). Se a Administração for usuária indireta, tem-se uma concessão de serviços públicos, na qual a remuneração incumbe, não ao usuário, mas ao Poder Concedente.

\footnotetext{
${ }^{33}$ A teor do art. 28 da Lei n 8.987/95 (que se aplica no ponto), as concessionárias poderão oferecer em garantia os direitos emergentes da concessão, até o limite que não comprometa a operacionalização e a continuidade da prestação do serviço.
}

A \& C R. de Dir. Administrativo e Constitucional, Belo Horizonte, ano 6, n. 23, p. 145-177, jan./mar. 2006 


\subsection{Da concorrência e da figura híbrida}

A PPP deve ser precedida de certame licitatório na modalidade concorrência, ${ }^{34}$ embora tenham sido incorporados elementos procedimentais do pregão. Tal combinação deveria ser feita com mais cautela, evitando-se a legítima controvérsia que nasce do fato de norma geral promover a combinação de modalidades, proibida noutra norma geral (a Lei de Licitações). Deve-se, ainda, tomar o extremo cuidado de jamais aceitar, na sucessão de lances, propostas inexequíveis, já pela restrição contida no art.12, $\S 1^{\circ}$, II da Lei de PPPs, já pela expressa vedação constante no art. 15 da Lei $\mathrm{n}^{\mathrm{o}} 8.987 / 95$. De conseguinte, em que pese proibida a combinação de modalidades licitatórias, nos termos do art. 22, parágrafo $8^{\circ}$ da Lei ${ }^{\circ}$ 8.666/93, o que o legislador fez, no art. 10 da Lei $\mathrm{n}^{\mathrm{o}} 11.079 / 2004$, foi estabelecer a concorrência e, por lapso, embaralhou tal modalidade com algo do pregão, ao estabelecer os critérios de julgamento, no art. 12. Trata-se de falha menor, mas que deve ser corrigida, pois a melhor técnica recomenda a alteração do conceito de concorrência, no corpo da Lei $\mathrm{n}^{\circ} 8.666 / 93$, de jeito a incluir o hibridismo (entre a concorrência com o pregão), no caso das PPPs.

\subsection{Do órgão gestor}

A PPP tem órgão gestor, na esfera federal, com o timbre de exacerbado "executivismo". De fato, ao versar sobre a competência do órgão gestor, no art. 14, hipertrofia-se a presença da Administração Direta, fazendo-o ter atribuições de definir os serviços prioritários para execução no regime de PPPs, disciplinar os procedimentos para celebração dos contratos, autorizar a abertura da licitação e aprovar edital, apreciar os relatórios de execução dos contratos. ${ }^{35}$ Mais: exige-se que, semestralmente, a Agência Reguladora preste contas ao órgão gestor (art. 15), numa aparente inversão de papéis. Está prescrito, ainda, que o órgão gestor deve remeter ao Congresso Nacional e ao Tribunal de Contas os relatórios de desempenho dos contratos de parceria público-privada, mas a relação com as Agências Reguladoras segue, para dizer o mínimo, nebulosa e impreciso o des-

\footnotetext{
34 Nos termos do art. $22, \S 1^{\circ}$, da Lei de Licitações, concorrência é "a modalidade de licitação entre quaisquer interessados que, na fase inicial de habilitação preliminar, comprovem possuir os requisitos mínimos de qualificação exigidos no edital para execução de seu objeto".

${ }^{35}$ No modelo, por exemplo, da Lei Estadual no 12.234/2005/RS, art. 20, o órgão gestor reajusta, revisa, delibera sobre o equilíbrio econômico-financeiro e assim por diante, apesar da modesta alusão final ao papel da Agência Reguladora correspondente (art. 33).
} 
dobramento da fiscalização das outorgas de concessão. ${ }^{36}$ Nesse passo, percebe-se, uma vez mais, quão inadiável é a melhor definição do processo regulatório, com descentralização da definição de prioridades dos recursos, ampliação do controle social ${ }^{37}$ e a aparição da inadiável Lei de Marcos Regulatórios, ${ }^{38}$ respeitadas situações funcionalmente específicas. Para dissipar a névoa, em nada ajuda o art. 15 da Lei no 11.079/2004, ao singelamente assinalar que compete aos Ministérios e às Agências Reguladoras, "nas suas respectivas áreas de competência". 39

\subsection{Da sociedade de propósito específico}

A PPP requer sociedade de propósito específico", ${ }^{40}$ que precisa observar padrões de "governança corporativa" (o que implica forte transparência de gestão). Em outras palavras, nisso diferindo das "concessões comuns", as PPPs devem ter parceiros privados constituídos, obrigatoriamente, como sociedades de propósito específico ("special purpose entity"), que apresentam acepção menos larga do que as EPEs (entidades de propósito específico). A SPE precisa, por definição, assumir forma societária personificada, como o nome sugere. A Lei de PPPs, no entanto, proíbe a Administração Pública de deter a maioria do capital votante $\left(\operatorname{art.} 9^{\circ}\right)$. Logo, a sociedade de economia mista não será, a rigor, SPE, pois esta precisa ser modalidade societária não-encartada na Administração Pública. Com efeito, na dicção do art. $9^{\circ}$, antes da celebração do contrato, "deverá" ser constituída sociedade de propósito específico, que poderá assumir até a forma de companhia aberta, desde que o parceiro público não detenha a maioria do capital votante, salvo se a aquisição da maioria ocorrer

\footnotetext{
${ }^{36}$ Sobre a competência do TCU para fiscalizar a atuação das Agências Reguladoras, vide, sobretudo, a Instrução Normativa n 27/98 daquela Corte de Contas, a qual, com pequenos ajustes, pode ser aplicada às PPPs, em que pese melhor termos a reclamada disciplina legal pacificadora. Vide, ainda, "Controle da Regulação no Brasil", do Ministro do TCU Walton Alencar Rodrigues in Revista Interesse Público, n. 33, 2005.

${ }_{37}$ Para além de mecanismos como o da formação de associações de usuários (vide, a propósito, o art. 29, XII da Lei $\left.n^{\circ} 8.987 / 95\right)$.

${ }^{38}$ Seria equívoco técnico grave reduzir a função regulatória ao papel das Agências Reguladoras. Em sentido largo, são reguladores, por exemplo, o BACEN e a CVM. Assim, a definição dos marcos regulatórios serve para fixar, em linhas gerais, as competências no sistema regulatório brasileiro, abrangendo especialmente a regulação de serviços públicos delegados e a regulação de atividades econômicas de relevante interesse coletivo, explicitando distinções e delimitando atribuições, sem deixar de estimular, quando possível, a ação sinérgica. No Direito Comparado, para exame didático das principais teorias sobre regulação, vide NEWBERY, David. Privatization, Restructuring and Regulation of Network Utilities. Londres: The MIT Press, 2001. p. 133-169.

${ }^{39}$ Nos termos do Decreto n 5.385/2005, na esfera federal, ficou instituído o Comitê Gestor de Parceria Público-Privada Federal - CGP, nos termos do art. 14 da Lei no 11.079/2004.

${ }^{40}$ Vide o conceito de "joint venture" de DRAKE, Charles. Law of Partnership. New York: Island Books, 1972. p. 233.
}

A \& C R. de Dir. Administrativo e Constitucional, Belo Horizonte, ano 6, n. 23, p. 145-177, jan./mar. 2006 
por instituição financeira controlada pelo Poder Público, na hipótese de inadimplemento. Ainda: a transferência do controle está condicionada à autorização expressa da Administração Pública, nos termos do edital e do contrato, observado o disposto no parágrafo único do art. 27 da Lei $\mathrm{n}^{\mathrm{o}}$ $8.987 / 95$, ou seja, a transferência sem prévia anuência implica a caducidade da concessão.

\subsection{Da pretensa atualização automática}

Numa recaída histórica na ingenuidade do automatismo preconizado pela Escola da Exegese, a Lei de PPPs apresenta mecanismo de "atualização automática". Força mencionar que, de há muito, o sistema determina o imediato reequilíbrio econômico-financeiro de todos os contratos. Entretanto, se atualização automática ocorrer por decurso de prazo, claro que pode engendrar conflito sistêmico, em vez de solução mais rápida. ${ }^{41}$ Não se vem admitido, com razão, o mero decurso de prazo, sequer nas revisões, muito menos nos reajustes. A leitura de que haveria, nesses casos, aprovação tácita, ainda que bem intencionada, esbarra nas dificuldades operacionais das Agências Reguladoras e dos seus controladores. Em outras palavras, se não houver a devida cautela, sai pela culatra o ganho em rapidez. A novidade está em, por lei, introduzir-se mecanismo (previsto no art. $5^{\circ}, \S 1^{\circ}$ ) pelo qual as cláusulas contratuais de atualização "automática" são aplicadas sem necessidade de homologação pela Administração Pública, exceto se esta publicar, na imprensa oficial, até o prazo de quinze dias após a apresentação da fatura, as razões para rejeitar a atualização. Nessa matéria, contudo, não se podem ocultar as eventuais rachaduras do reajuste ou da revisão com o papel de parede bem decorado pelo suposto automatismo. O essencial é haver uma cultura de intangibilidade do equilíbrio econômico-financeiro. Força reconhecer que, infelizmente, na vida real, não basta afirmar que a atualização será fruto de mera subsunção, pois somente a ambiência institucional adequada tem o condão de afugentar os crônicos (nem sempre inocentes) desequilíbrios econômico-financeiros dos contratos públicos, bem como os calotes impunes e a ausência de real partilha dos riscos e dos ganhos de eficiência.

\subsection{Das competências}

A PPP é fiscalizada pela Administração Direta, pelo Tribunal de

\footnotetext{
${ }^{41}$ Sobre o tema, vide Acórdão n 232/2002 do TCU.
}

A \& C R. de Dir. Administrativo e Constitucional, Belo Horizonte, ano 6, n. 23, p. 145-177, jan./mar. 2006 
Contas e pelas Agências Reguladoras, nas respectivas competências. Como referido, soa nada esclarecedor art. 15, isto é, perde ocasião de elucidar os papéis. Poderia ter deixado, por exemplo, límpido o papel de controle do Tribunal de Contas, assim como deveria ter proibido que a Agência Reguladora figurasse como Poder Concedente. Enfim, poderia ter elucidado quem decreta a caducidade ou quem se encarrega da revisão e do reajuste. $\mathrm{E}$, como visto, na dicção do parágrafo único do art. 15 , as Agências Reguladoras encaminharão ao órgão gestor relatórios periódicos sobre a execução dos contratos, dando a impressão de submissão das Agências ao órgão gestor. Dito outra vez, falta definição nítida e segura das respectivas competências, como basilar e irrenunciável condição para reduzir os riscos regulatórios.

\subsection{Da consulta pública ou da preferível audiência pública}

A PPP deve ser precedida de Consulta Pública de sua minuta de edital e do contrato. Reza o art. 10, VI, da Lei ${ }^{\circ} 11.079 / 2004$, que a abertura do processo licitatório encontra-se condicionada à submissão da minuta do edital e do contrato à consulta pública, nos prazos ali estabelecidos. Louvável exigência, mas melhor - e constitucionalmente mais pertinente - seria realizar Audiência Pública, no resguardo do princípio da democracia participativa. ${ }^{42}$ A consulta é mecanismo passivo (nada interativo), que se traduz, no geral das vezes, em simples e inócuo envio de sugestões. Mesmo nela, contudo, a rejeição das sugestões deve ser suficientemente motivada. Superior democraticamente, a Audiência Pública é derivação da eficácia plena e imediata do princípio constitucional da democracia $\left(\mathrm{CF}\right.$, art. $\left.1^{\circ}\right){ }^{43}$ Bem por isso, em nada se incompatibiliza com as normas gerais da Lei $\mathrm{n}^{\circ} 11.079 / 2004$, no ponto, a Lei estadual $\mathrm{n}^{\mathrm{o}}$ 12.234/2005 do RS, ao exigir Audiência Pública (art. $6^{\circ}, \S^{\circ}$ ).

\subsection{Do projeto básico}

Em função de veto presidencial, a PPP admite que o interessado elabore o projeto básico, não apenas o projeto executivo. Mister trazer à colação as razões do veto ao inciso II do art. 11: "As parceiras públicoprivadas só se justificam se o parceiro privado puder prestar os serviços

\footnotetext{
42 Vide, por obséquio, FREITAS, Juarez. O Controle dos Atos Administrativos e os Princípios Fundamentais, op. cit., Cap. 2

${ }^{43}$ Para uma visão do tema, no Direito Comparado, vide Greg Palast. OPPENHEIM, Jerrold; MacGREGOR, Theo. Democracy and Regulation. How the Public can Govern Essential Services. London: Pluto Press, 2003.
} 
contratados de forma mais eficiente que a administração pública (exigível, assim, execução mais célere, econômica e qualificada dos projetos). Este ganho de eficiência pode advir de diversas fontes, uma das quais vem merecendo especial destaque na experiência internacional: a elaboração dos projetos básico e executivo da obra pelo parceiro privado." Não há maior dúvida que se tem aqui um passo ousado na tendência já presente na Lei $\mathrm{n}^{\circ} 9.074 / 95$, ao admitir que os autores ou responsáveis pelo projeto básico participem da licitação ou da execução de obras ou serviços. Embora reine a tradição de somente se delegar o projeto executivo, não custa rever a matéria, desde que o Poder Concedente afugente qualquer vestígio de direcionamento. De mais a mais, não se torna inaplicável, no ponto, o art. $18, \mathrm{XV}$, da Lei $\mathrm{n}^{\circ} 8.987 / 95$, pois continuarão requeridos os elementos do projeto básico que permitem a plena caracterização do objeto.

\subsection{Do dever de motivação clara e congruente}

Mostra-se inafastável o dever de motivar, consistentemente, a escolha desse tipo de contratação, em função das singulares vantagens e garantias. Imprescindível que as "vantagens socioeconômicas", associadas à "sustentabilidade" dessa opção pairem acima de suspeitas. Como asseverado — no exame da característica (a) — entre a remuneração com tarifa módica (preço público) e a remuneração subvencionada, preferível a primeira. Entre a subvencionada e a remuneração integral pelo Poder Público, justificável aquela. A par disso, as vantagens não devem ser estritamente econômicas, mas compensatórias e sociais, tendo em vista a natureza do serviço eminentemente universal em apreço. Tal dever é decorrência, ainda, do art. 50 da Lei de Processo Administrativo, que não aceita qualquer motivação, mas a exige clara e congruente.

\subsection{Da segurança para os financiadores}

Alusivamente à característica (s), a PPP brasileira quer propiciar mais segurança para financiadores dos recursos financeiros necessários à prestação do serviço, até para reduzir os "spreads". As próprias garantias especiais ajustadas com o parceiro privado (ex.: fundo fiduciário) são indiretamente garantias para os financiadores, que tendencialmente serão bancos de desenvolvimento ou multilaterais. Há faculdades que impressionam, nessa linha: está dito que os contratos de parceria públicoprivada poderão prever requisitos e condições em que o parceiro público

A \& C R. de Dir. Administrativo e Constitucional, Belo Horizonte, ano 6, n. 23, p. 145-177, jan./mar. 2006 
autoriza a transferência do controle da sociedade de propósito específico para os financiadores, com o objetivo de promover a reestruturação financeira e de assegurar a continuidade dos serviços. Mais: confere-se possibilidade de emissão de empenho em nome dos financiadores do projeto em relação às obrigações pecuniárias da Administração Pública e, ainda, a legitimidade para receber indenizações por extinção antecipada do contrato, assim como os pagamentos efetuados pelos fundos e empresas estatais garantidores das PPPs. ${ }^{44}$ Esses mecanismos, entretanto, precisam de declaração de constitucionalidade, convindo que seja intentada a ADC para esse efeito. Ademais, a maior garantia, não custa sulcar, está na modelagem regulatória, a ser estabelecida.

\subsection{Da resolução de conflitos}

No atinente à característica (t), isto é, a busca de solução mais rápida para os conflitos e da redução dos custos de transação, o legislador das PPPs apela à arbitragem privada e descura de incentivar expressamente a arbitragem pública, a cargo das Agências Reguladoras, que devem estar melhor equipadas para essa tarefa precípua. Nos termos do art. 11 da Lei $\mathrm{n}^{\mathrm{o}}$ 11.079/2004, acolhe-se, então, o emprego de mecanismos privados de resolução de disputas, inclusive a arbitragem, desde que realizada no Brasil e em língua portuguesa. Passível de interpretação conforme, o dispositivo da Lei ${ }^{\circ}$ 11.079/2004, contudo, não deve ser visto como solução mágica, nem afastar a prioritária função arbitral das Agências reguladoras. É que não se podem devem ignorar os ponderáveis riscos de eventual nulidade (ou contestação morosa) da arbitragem privada. Além disso, convém ter presentes aspectos relevantes da Lei $\mathrm{n}^{\circ}$ 9.307/96, que versa sobre arbitragem. Ei-los: em seu art. $1^{\circ}$, a Lei da Arbitragem prescreve que as pessoas capazes de contratar poderão valer-se dela para dirimir litígios relativos somente a direitos patrimoniais disponíveis. A teor do art. 25, sobrevindo no curso da arbitragem uma controvérsia acerca de direitos indisponíveis e verificando-se que de sua existência, ou não, depende o julgamento, o assunto será remetido à autoridade competente do Poder Judiciário, suspendendo-se o procedimento arbitral. Ainda: segundo o art. $8^{\circ}$, a cláusula compromissória é autônoma em relação ao contrato em que estiver inserta, de sorte que a nulidade deste não implica, necessariamente, a nulidade da cláusula compromissória. O árbitro, nos termos do art. 18,

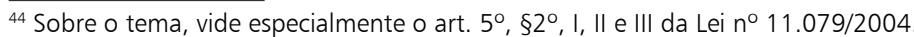

A \& C R. de Dir. Administrativo e Constitucional, Belo Horizonte, ano 6, n. 23, p. 145-177, jan./mar. 2006 
é, em termos, "juiz de fato e de direito", pois, apesar de a sentença que proferir não ficar sujeita a recurso ou homologação pelo Poder Judiciário, cabe argüição judicial de nulidade, como reconhece o art. 32 da Lei de Arbitragem. Assim, a parte prejudicada (admitida a ação popular) pode pleitear ao Poder Judiciário a decretação da nulidade da sentença arbitral, o que significa risco de judicializar conflitos, em vez de antecipar a resolução, como se pretende. Sem excluir, por conseguinte, a arbitragem privada e com o desiderato de evitar o aumento dos custos de transação e das externalidades negativas, não se deve desconsiderar a função arbitral (em sentido lato) a ser exercida pelas Agências Reguladoras, que, também por isso, precisam ser independentes em relação ao Poder Concedente, com dirigentes de recrutamento despartidarizado, ao máximo. ${ }^{45}$ Relevante e inadiável, pois, definir o papel arbitral e conciliatório das Autarquias Reguladoras de regime especial.

No entanto, não se vislumbra inconstitucionalidade na adoção da arbitragem privada como alternativa, seja porque (i) o princípio da indisponibilidade do interesse público não é absoluto, existindo previsão de foro amigável na Lei ${ }^{\circ} 8.987 / 95$, art. 23, XV, (ii) seja porque argumento insuperável — o laudo arbitral bem realizado não contraria $o$ interesse público, sob pena de vício e (iii) seja porque permanece vedada qualquer arbitragem sobre direitos indisponíveis. ${ }^{46}$ Apesar disso, o emprego de mecanismos privados na resolução de disputas com o Poder Concedente $^{47}$ tende a, nessa altura, lançar mais polêmica do que luz, ou seja, o melhor é, sem descartar a alternativa, estabelecer a competência, no âmbito das Agências Reguladoras, para arbitrar soluções prontas e rápidas na composição de interesses legítimos. A busca de alternativas públicas, sem recurso hierárquico ao Executivo, aponta para novas feições do Direito Administrativo: menos unilateral, mais dialógico e conciliatório.

\subsection{Do objeto}

No que diz respeito ao objeto, a PPP não se confunde com terceirização, encontra-se inserida no art. $2^{\circ}, \S 4^{\circ}$, II, da Lei $n^{\circ} 11.079 / 2004$. Vedado o ajuste de PPP quando o único objeto for o fornecimento de mão-de obra, preocupação que se encontra, por igual, no âmbito das leis

\footnotetext{
45 Não é acaso que as Agências são autoridades administrativas independentes, em boa parte do Direito Comparado, ainda que com mandatos dos seus dirigentes.

${ }^{46}$ A Lei no 12.234/2005 de PPPs, do Rio Grande do Sul, teve cuidado de referir arbitragem para "aspectos previamente delimitados" (art. 60, III, "d").

47 Para um cotejo no Direito Comparado, vide a clara exposição de José Esquível (Os Contratos Administrativos e a Arbitragem. Coimbra: Almedina, 2004, especialmente os Capítulos IV e V).
} 
estaduais de PPP. A propósito, as terceirizações devem obedecer os limites do art. 72 da Lei Complementar $n^{\circ} 101$ e nada mais são do que contratos de prestação (ou "locação", na linguagem antiga) de serviços prestados à Administração Pública (relacionados à atividade inerentemente instrumental), tendo esse único objeto. Já na PPP, atribui-se a execução a terceiro para que este preste o serviço, algo tecnicamente inconfundível com o que sucede na terceirização ou com o fornecimento de mão-deobra. Verdade que a chamada "concessão administrativa" situa-se na zona de fronteira. Contudo, deve-se evitar, a todo transe, a confusão técnica entre as noções de PPP (com riscos partilhados) e a de mera "locação" de serviços, secundários e acessórios em relação a atividades vitais do Estado.

\subsection{Das normas gerais}

De acordo com a característica (v), a PPP é introduzida por "normas gerais", consoante o disposto no art. $1^{\circ}$, da Lei ${ }^{\circ} 11.079 / 2004$, no âmbito dos Poderes da União, dos Estados, do Distrito Federal e dos Municípios, em harmonia com o art. 37, XXI da CF. Incontendível que há normas, nesse diploma, que são apenas federais, mas preponderam as gerais. Há disposições equivocadas, tais como as que estabelecem limites diferenciados em relação ao IDH de apenas algumas regiões. Há outras que melhor estariam numa Lei Complementar, pois inovam sobre responsabilidade fiscal. Há, também, lacunas severas. Por exemplo, falta dizer qual a relação entre PPPs e consórcios públicos, tema nevrálgico em matéria de saneamento. Para além disso, não raro, o legislador sucumbe à tentação de pretender tornar especial a norma geral. Por exemplo, diz que as "concessões patrocinadas" regem-se pela Lei de PPPs, aplicandose-lhes "subsidiariamente" o disposto na Lei $\mathrm{n}^{\circ}$ 8.987/95. Trata-se de redação assaz defeituosa. Outra ilustração: quando diz que continuam regidos exclusivamente pela Lei $n^{\circ} 8.666 / 93$ e pelas leis que lhe são correlatas os contratos administrativos que não caracterizem concessão comum, patrocinada ou administrativa. Nesse ponto, o equívoco dimana da confusão conceitual de partida, já comentada, em relação ao art. $2^{\circ}$ da Lei $\mathrm{n}^{\mathrm{o}} 11.079 / 2004$. A despeito de tudo, as leis estaduais e municipais precisam ser lidas em harmonia com as "normas gerais" autênticas, de maneira que não poderão, por exemplo, alargar as hipóteses de PPPs nem destoar do regramento nacional.

\subsection{Dos critérios de julgamento}

No pertinente à característica $(\mathrm{x})$, a PPP pode ter licitação que adote

A \& C R. de Dir. Administrativo e Constitucional, Belo Horizonte, ano 6, n. 23, p. 145-177, jan./mar. 2006 
critérios que incluam o exame de propostas econômicas, ou seja, aquelas que tratam do menor valor da contraprestação (art. 12, II, "a" da Lei de PPPs) ou menor valor da tarifa (art. 13, I da Lei no 8.987/95 é aplicável no ponto), sem prejuízo da combinação com a técnica. Na prática, não deve ser descurada a contemplação das receitas alternativas. Ao mesmo tempo, acolhe-se, em boa hora, a possibilidade de inversão da ordem das fases de habilitação e julgamento, flexibilidade que deve ser, o mais breve possível, estendida às "concessões comuns".

\subsection{Do índice de desenvolvimento humano}

Por fim, a PPP tem parcela de seus limites variando conforme o Índice de Desenvolvimento Humano, admitindo maior elasticidade nas zonas de IDH mais baixo. Nisso, o legislador merece louvores. O equívoco, corrigível hermeneuticamente, foi o de ter adotado tal solução apenas para as regiões norte, nordeste e centro-oeste, em nova afronta à Federação. A preocupação com IDH merece encômios, pois representa medida concreta tendente a reduzir desigualdades sociais e regionais, um dos objetivos máximos de nossa República.

\section{PPP e regulação: mudanças necessárias no ambiente dos negócios públicos}

A regulação ${ }^{48}$ de PPPs deve integrar o espírito de mudanças institucionais emergentes do que há de melhor nas transformações do Direito Administrativo. ${ }^{49}$ Para a formação de uma confiável atmosfera de negócios públicos, a atividade exclusivamente estatal de regulação, notadamente a exercida por Agências Reguladoras, precisa experimentar mudanças

\footnotetext{
48 Tomo a regulação, nesse estudo, em sentido administrativo (sem desconsiderar que a expressão possa ter acepção ampla, abarcando até a regulação legal), como elemento do exercício de restringir o exercício dos direitos de liberdade e de propriedade, na esfera administrativa (infralegal, em nosso sistema). Sobre o tema, vide Capítulo 8 de meu O Controle dos Atos Administrativos e os Princípios Fundamentais, op. cit., no qual defini o "poder de polícia administrativa", em tais termos: "o exercício do dever (não mera faculdade), que consiste em regular, restringir ou limitar administrativamente, de modo legal e legítimo, o exercício dos direitos fundamentais de propriedade e de liberdade, de maneira a obter, mais positiva do que negativamente, uma ordem pública capaz de viabilizar a coexistência dos direitos fundamentais em sua totalidade, sem render ensejo à indenização, por não impor dano injusto." Sobre regulação, confira-se, ainda, o conceito de Alexandre Aragão (Agências Reguladoras. 2. ed. Rio de Janeiro: Forense, 2003, p. 37). Vide, também, DI PIETRO Maria S. Z. Direito Regulatório: Temas Polêmicos. Belo Horizonte: Fórum, 2003. p. 30; SOUTO, Marcos Juruena Villela. Função Regulatória. Revista Diálogo Jurídico, Salvador: CAJ, n. 11, fev., 2002; FIgueiredo, Pedro H. A Regulação do Serviço Público Concedido. Porto Alegre: Síntese, 1999. p. 40; JUSTEN FILHO, Marçal. O Direito das Agências Reguladoras Independentes. São Paulo: Dialética, 2002. p. 27 e Curso de Direito Administrativo. São Paulo: Saraiva, 2005. p. 447 (tratando de "regulação econômicosocial").

${ }^{49}$ Eis as principais transformações do Direito Administrativo contemporâneo: (a) O jovem Direito Administrativo está deixando de ser monológico para se tornar dialógico e aberto, menos unilateral ou impositivo: trata-se
} 
sensíveis.

Em primeiro lugar, a regulação deve abandonar a hipertrofia das práticas de imposição unilateral autoritária e de inobservância dos limites legais, ${ }^{50}$ reconhecendo a primazia da conciliação, da arbitragem e da mediação. Em segundo lugar, a regulação deve desenvolver competência técnica, isto é, investir em qualificação específica dos agentes reguladores, além de lutar por autonomia financeira efetiva, não sujeita a contingenciamentos orçamentários e sem que o "contrato" ${ }^{1}$ de gestão, previsto no art. $37, \S 8^{\circ}$ da $\mathrm{CF}$ represente ingerência ou desvirtuamento do controle de performance. Em terceiro lugar, a regulação de PPPs

de lenta transformação que permite viabilizar, por exemplo, fórmulas de transação, conciliação e acordos preliminares à edição de atos administrativos, mormente em face da fragmentação da idéia de supremacia da Administração Pública (antiga característica do século XIX e da maior parte do século XX), fenômeno que se explica, em larga medida, pela relativização mútua dos princípios. (b) Mingua o espaço da discricionariedade, substituída, a pouco e pouco, pela noção de liberdade vinculada e justificável racionalmente, sem sucumbir a particularismos contrários à idéia de universalização, de modo que toda discricionariedade (no plano dos mandamentos - Tatbestand — ou na eleição das conseqüências) resta vinculada aos princípios fundamentais, donde se extrai a inexistência de discricionariedade pura. (c) Cobra-se, mais e mais, o exercício fundamentado do poder estatal, inclusive do chamado "poder de polícia administrativa". Vale dizer, a exigência alastrada de motivação surge como antídoto contra a arbitrariedade entendida como o exercício autofágico e coisificante do poder pela ausência de fundamentação reflexiva e conseqüente quebra da vocação para a sistematicidade. (d) O Direito Administrativo aparece menos como o Direito do Estado precipuamente prestador (executor direto) dos serviços públicos ou universais (se se preferir o termo ao gosto europeu) para se converter em Direito do Estado Regulador, ao mesmo tempo em que começa a deixar de ser plexo de normas viciadas pelo executivismo crônico (mormente no presidencialismo que se caracteriza pela concentração unipessoal das Chefias de Estado e de Governo). Assume, em razão disso, a condição de promotor de políticas públicas que transcendem o curto período dos mandatos governamentais. A continuidade pósgovernamental e o planejamento passam a ter papel maiúsculo na construção da efetividade do complexo de princípios que regem as relações de administração. As Agências Reguladoras, em face dessas transformações, tendem a ser independentes e efetivamente autárquicas - "terceiras" nas relações com o governo, inclusive para bem cumprir as funções conciliatórias. (e) Categorias outrora rígidas passam a ser flexibilizadas e sadiamente indeterminadas (embora determináveis pelo aplicador), sem que se aceite uma exacerbada vinculação napoleônica, tão cara à Escola da Exegese, de modo que avança a mitigação do princípio da legalidade, havendo atividades administrativas exigíveis independentemente de previsão legal. (f) Observa-se o aumento da incidência formal (no plano das regras) do Direito Privado nas relações de administração, mas se afirma, aos poucos, a preponderância principiológica publicista, sobrepassando-se, em grande parte, as "exorbitâncias" antigas, em face do fenômeno da constitucionalização de todo Direito. (g) Tende-se a exigir a menor precariedade possível nas relações de administração para se viabilizarem investimentos produtivos e de longo prazo, preparando terreno para, entre outros efeitos, a modicidade das tarifas públicas e o equilíbrio econômico-financeiro que contemple o consumidor de serviços públicos e, ao mesmo tempo, os interesses legítimos, dos parceiros privados (PPPs). (h) Está o cidadão (não mais um simples "administrado") passando a ser (embora vulnerável) proativo e protagonista, menos passivo e súdito. (i) Passou-se a robustecer a incidência do princípio da democracia (direta e indireta), já não se mostrando especulativa, por exemplo, a hipótese de declaração de inconstitucionalidade de uma lei aprovada sem a realização de audiências públicas, por ofensa ao princípio da participação. Na seara propriamente das relações administrativas, avulta a obrigatoriedade de realização de audiências públicas como condição de validade de atos e procedimentos administrativos. (j) Desenvolve-se, nas relações de administração, 0 primado dos direitos fundamentais, avultando o papel do princípio da dignidade humana na definição de conteúdo e de alcance dos demais princípios.

${ }^{50}$ Nesse aspecto, merece menção o julgamento histórico da ADin $n^{\circ} 1.688$, quando o STF deferiu, em parte, o pedido de medida cautelar, para, quanto aos incisos IV e X, do art. 19 da Lei $n^{\circ}$ 9.472, sem redução de texto, dar-Ihes interpretação conforme à Constituição Federal, com o objetivo de fixar exegese segundo a qual a competência da Agência Nacional de Telecomunicações para expedir normas subordinase aos preceitos legais e regulamentares que regem outorga, prestação e fruição dos serviços de telecomunicações."

A \& C R. de Dir. Administrativo e Constitucional, Belo Horizonte, ano 6, n. 23, p. 145-177, jan./mar. 2006 
deve alcançar equilíbrio proporcional entre retornos econômicos e sociais, ${ }^{52}$ na salvaguarda do direito fundamental à intangibilidade da equação econômico-financeira, bem como na partilha dos ganhos e benefícios não apenas com o parceiro público, mas com o usuário. A este deve ser assegurado o direito fundamental à fruição acessível e universalizada do serviço público de qualidade. Em quarto lugar, a regulação de PPPs precisa ser socialmente controlada, assim como a atuação do órgão gestor. Com efeito, o controle social não exclui os demais controles, mas a eles deve ser somado sinergicamente. Nessa linha, mais do que consultas públicas, como salientado, devemos assimilar a obrigatoriedade das audiências públicas em todas as decisões relevantes das Agências Reguladoras. Dito de outro modo, em vez do temor excessivo de "captura" ou de cooptação, a postura correta está em se abrir à sociedade, estimulando-a a construir, preferencialmente, padronizações voluntárias. ${ }^{53}$ Em quinto lugar, no crucial momento de definição da arquitetura do novo sistema regulatório, força apostar na reforma institucional que consagre as Agências Reguladoras como pessoas de Estado, mais do que de governo, em que pese integrarem a Administração indireta. Tal independência moderada supõe opção filosófica e política, no sentido de que são quatro, e não três, os pólos da relação plurilateral de PPPs. O modelo triádico (parceiro público, parceiro privado e usuário) revela-se insuficiente, isto é, não se coaduna com a desejável política regulatória autônoma e de longo prazo, porque prejudica a continuidade e turba a credibilidade. Faz-se imprescindível, pois, acrescentar um pólo no desenho das relações jurídicas de delegação, a saber, além do parceiro público, do parceiro privado e do usuário, mister incluir a figura do regulador, sem debilitar o controle externo sobre tal relação. Opta-se, por conseguinte, pela regulação como pólo autônomo, não apêndice nem braço do concedente, quando se preconizam relações confiáveis e tecidas no longo prazo (até trinta e cinco anos). ${ }^{54}$ Não se trata de postular que a independência redunde em clima de hostilização entre Agência e Poder Concedente. Ao contrário. As Agências Reguladoras não devem agir como inimigas do

\footnotetext{
${ }^{51}$ A depender do acordo semântico, é manifesto que não se trata de contrato, mas simples compromisso de cumprimento de metas. Importa é que tais metas não se confundam com a interferência indevida sobre a indelegável atividade regulatória.

52 Vide McCRUDDEN, Christopher. Social Policy and Economic Regulators. In: Regulation and Deregulation. Oxford: Oxford University Press, 1999. p. 275-291.

53 Sobre as vantagens da padronização voluntária, vide DEMING, E. As 14 Lições Definitivas sobre Controle de Qualidade. São Paulo: Futura, 2003. p. 210.
} 
Poder Concedente, muito menos do usuário. Devem promover a solidária atuação conjunta em favor do serviço adequado. No modelo sugerido, a regulação não guarda identidade com o titular do serviço, isto é, com o parceiro público, opção de capital importância, ainda mais no presidencialismo, tendente a excessos. A regulação precisa, institucionalmente, constitui a estabilidade das regras do jogo, em meio às incertezas características de nosso tempo. ${ }^{55}$ Para tanto, o vínculo dos agentes reguladores deve ser o institucional ou estatutário, ${ }^{56}$ não o contratual, salvo em relação àqueles que não desempenham atividades tipicamente regulatórias. A própria Lei de PPPs deixa translúcido o caráter indelegável dessa missão estatal exclusiva. Em suma, a regulação deve ser vista como tarefa do Estado, mais do que de governo, no rumo de uma nova tradição regulatória que transcenda o episódico e o transitório, ou seja, o estritamente governamental. A Agência Reguladora é — ou deveria ser — independente e, como sublinhado, não pode efetuar definição política setorial. ${ }^{57} \mathrm{Em}$ sexto lugar, deve a regulação evitar o erro $\operatorname{comum}^{58}$ do facciosismo: o seu objetivo máximo é o de tutelar a pluridimensionalidade da delegação contratual, não hesitando, se for o caso, em adotar medidas sancionatórias até em relação às pessoas jurídicas de direito público. Em se dando conta desse papel primordial redutor de assimetrias e confrontos negativos, ${ }^{59}$ resolverá, com mais facilidade, os potenciais conflitos e os custos correspondentes, evitando demandas judiciais e o próprio recurso à arbitragem

54 Vide o Projeto de Lei n³ 3.337/2004

${ }^{55}$ Sobre as instituições como regras do jogo em sociedade, por todos, vide NORTH, Douglas. Institutions, Institutional Change, and Economic Performance. New York: Cambridge University Press, 1990.

${ }^{56}$ Vide, a propósito, a Lei $n^{\circ} 10.871 / 2004$. Com efeito, era inconstitucional o regime celetista, previsto na Lei $n^{\circ} 9.986 / 2000$, dado que os agentes reguladores precisam ter a garantia da estabilidade do art. 41 da CF, entre outras, razões por desempenharem função estatal exclusiva. A Lei no 10.871 , ao tratar das carreiras das Agências Reguladoras, na esfera federal, criou, para exercício exclusivo nestas autarquias especiais, os cargos que compõem as carreiras de regulação de serviços públicos de telecomunicações, regulação da atividade cinematográfica e audiovisual, regulação de recursos energéticos, regulação de petróleo e derivados, álcool combustível e gás natural, regulação de saúde suplementar, regulação de serviços de transportes aquaviários e de transportes terrestres, regulação de serviços sob vigilância sanitária, entre outros. Mais: nos termos do art. $6^{\circ}$, o regime dos cargos e carreiras referidos no art. $1^{\circ}$ desta Lei é o instituído na Lei $n^{\circ} 8.112 / 90$, não o celetista. São, pois, cargos efetivos. Ademais, restaram extintos, em boa hora, nos termos do art. 24, empregos públicos (celetistas e sem garantias) de nível superior de regulador.

${ }^{57}$ Aqui, verifica-se que a regulação precisa ser incorporada ao conceito de "poder de polícia administrativa", inescapavelmente. Ademais, há, para citar exemplo, regulação também no uso adequado do meio ambiente, bem de uso comum do povo, na linguagem da Constituição. Evidente que também é regulatória a atividade administrativa estatal (no fundo, exercício de "polícia administrativa", como explicado) de proteção do consumidor, nos termos da Lei n 8.078/90 (tema que mereceu tratamento destacado em meu O Controle dos Atos Administrativos e os Princípios Fundamentais, op. cit). No entanto, a atividade das Agências Reguladoras tem-se concentrado em disciplina de serviços delegados e de atividades econômicas de relevância coletiva.

${ }^{58}$ Como enfatizado, a referência às Agências Reguladoras não é - nem poderia ser — excludente de outras atividades regulatórias. Vide, ainda, SUNDFELD, Carlos Ari. Introdução às Agências Reguladoras. Direito Administrativo Econômico. São Paulo: Malheiros.

A \& C R. de Dir. Administrativo e Constitucional, Belo Horizonte, ano 6, n. 23, p. 145-177, jan./mar. 2006 
privada. Assim, a função mediadora e solvedora dos conflitos assume a condição de inerentemente regulatória. Em sétimo lugar, o Estado Regulador $^{60}$ (que, na ótica esposada, disciplina, na esfera administrativa, os serviços públicos delegados e as atividades econômicas de relevante interesse coletivo) tem o dever de observância do sistema, mais do que da lei. Não pode praticar o não-Direito. Nessa medida, as Agências não devem inovar como se legisladoras fossem, pois precisam zelar por princípios fundamentais, tais como o da soberania popular e o da distribuição competencial dos poderes. Devem atuar como guardiãs sistemáticas das expectativas legítimas, marcadamente no caso da partilha de riscos. Em oitavo lugar, a regulação deve operar como redutora eficiente e eficaz dos custos de transação. Abordagem diversa resulta fatal, a longo termo. Vale dizer, se houver desequilíbrio contratual, imediatamente deve ser recomposto o equilíbrio, evitando-se os custos iníquos da morosidade, seja na revisão, seja no reajuste, independentemente da fórmula de "atualização automática". Em nono lugar, a regulação deve ser promotora do desenvolvimento em sentido largo ${ }^{61}$ sobressaindo a idéia de desenvolvimento humano, de sorte a incorporar, vez por todas, preocupações dessa natureza, algo que só acontece, de maneira tímida no âmbito da Lei de PPPs. Em décimo lugar, a regulação é função que, acima de tudo, deve inspirar confiança, o que requer a máxima transparência. ${ }^{62}$

Eis, em síntese, o decálogo de propostas voltadas a renovar a regulação brasileira, institucionalmente redesenhada, de maneira consentânea com as contratações administrativas e com a plena consolidação do novo paradigma comportamental na área dos negócios públicos, favorável a parcerias fecundas e produtivas, ética e economicamente.

\section{Conclusões}

Por todo o exposto, o novo regime de Parcerias Público-Privadas, introduzido pela Lei Federal $n^{\circ} 11.079$, carrega várias atecnias e imper-

\footnotetext{
59 Vide SAlOMÃO, Calixto. Regulação da Atividade Econômica (Princípios e Fundamentos Jurídicos). São Paulo: Malheiros, 2001. p. 15.

${ }^{60}$ Bem a calhar, vide MAJONE, Giandomenico; LA SPINA, Antonio. Lo Stato Regulatore de Bologna: II Mulino, 2000. p. 28.

${ }^{61}$ Vide SEN, Amartya. Desenvolvimento como Liberdade. São Paulo: Cia das Letras, 2000, tomando o desenvolvimento como um processo de expansão das liberdades substantivas e a capacidade humana como expressão da liberdade (sobretudo, p. 284-337).

62 Vide, na esfera privada, sobre a transparência e as suas vantagens, especialmente em parcerias (p. 127 et seq.), TAPSCOTT, Don; TICOLL, David. A Empresa Transparente. São Paulo: MBooks, 2005.
} 
feições que precisam ser escoimadas. Trata-se, pois, de legislação que demanda imensos desafios interpretativos e complementares transformações normativas para operar como fator benéfico de crescimento sustentado e socialmente justo. Os principais desafios para a adequada viabilização das PPPs, no contexto brasileiro, são: (a) a definição de competências regulatórias, oportunidade desperdiçada no art. 15 da Lei de PPPs, pois se faz necessário dar ciência meridiana do papel das Agências, missão que deve ser diferenciada em relação ao Poder Concedente; não menos imperioso saber o papel institucional dos Tribunais de Contas na matéria, dado que controlam as Agências Reguladoras, não apenas nas suas atividades-meio; (b) a definição das titularidades (caso do saneamento); (c) a elucidação cabal dos casos de dívida pública ou despesas de caráter continuado, no exame da contraprestação do Poder Público; (d) uma lei complementar de descentralização do licenciamento ambiental, que implante sistema cooperativo e racional; (e) o exame rápido, pelo STF, da constitucionalidade do FGP e de outras fontes de garantia; (f) o aperfeiçoamento da Lei de Processo Administrativo, disciplinando prazos e ritos regulatórios; (g) a solução preferencialmente pública dos conflitos, criada a mentalidade mediadora e arbitral dos entes regulatórios e do próprio Poder Concedente; (h) o rigoroso controle externo de acompanhamento na execução dos contratos, sem ênfase às auditorias "a posteriori", inclusive pelo longo prazo que caracteriza essa modalidade contratual, evitando-se, cautelarmente, a prática de subsídios demagógicos, na hipótese de "concessão patrocinada"; (i) o controle de consistência da motivação da escolha de tais "concessões" peculiares, convindo sulcar que, sempre que viável, serão preferíveis, por economicidade, as "concessões comuns"; (j) o incentivo ao controle social, já no âmbito do órgão gestor, já no âmbito das aconselháveis audiências públicas (em lugar de meras consultas) para fiscalizar o processo licitatório; (k) a geração da cultura de planejamento de longo prazo, em harmonia com os ditames da responsabilidade fiscal; (l) o combate eficiente e eficaz aos desequilíbrios econômico-financeiros dos contratos administrativos, sem aposta no ingênuo mecanismo de "atualização automática", bem como a realização de contratos com a devida distribuição de riscos, tendo presente a essencialidade dos serviços em apreço, que aconselha a máxima redução dos riscos à continuidade da execução contratual.

Em última análise, impõe-se ousar novos passos: mais compromisso

A \& C R. de Dir. Administrativo e Constitucional, Belo Horizonte, ano 6, n. 23, p. 145-177, jan./mar. 2006 
com a consistência regulatória, cristalina distribuição de competências, dissipação de dúvidas quanto às titularidades e acerca da natureza infralegal da atividade regulatória. Tudo visando à manifesta compatibilização (formal e material) das normas gerais que incidem, direta ou indiretamente, sobre as PPPs, com os novos rumos do Direito Administrativo brasileiro: mais dialógico, dignificante e democrático, voltado à edificação do Estado Proporcional de Direito e à tutela efetiva, no núcleo essencial, dos direitos fundamentais.

Informação bibliográfica deste texto, conforme a NBR 6023:2002 da Associação Brasileira de Normas Técnicas (ABNT):

FREITAS, Juarez. Parcerias Público-Privadas (PPPs) e desafios regulatórios. A\&C Revista de Direito Administrativo e Constitucional, Belo Horizonte, ano 6, n. 23, p. 145-177, jan./ mqr. 2006. 